Portland State University

PDXScholar

Summer 8-5-2016

\title{
The Making of Modern Egypt: the Egyptian Ulama as Custodians of Change and Guardians of Muslim Culture
}

Marai Boauod

Portland State University

Follow this and additional works at: https://pdxscholar.library.pdx.edu/open_access_etds

Part of the Islamic Studies Commons, and the Islamic World and Near East History Commons Let us know how access to this document benefits you.

\section{Recommended Citation}

Boauod, Marai, "The Making of Modern Egypt: the Egyptian Ulama as Custodians of Change and Guardians of Muslim Culture" (2016). Dissertations and Theses. Paper 3102.

https://doi.org/10.15760/etd.3099

This Thesis is brought to you for free and open access. It has been accepted for inclusion in Dissertations and Theses by an authorized administrator of PDXScholar. Please contact us if we can make this document more accessible: pdxscholar@pdx.edu. 
The Making of Modern Egypt:

The Egyptian Ulama as Custodians of Change and Guardians of Muslim Culture

by

Marai Boauod

A thesis submitted in partial fulfillment of the requirements for the degree of

\author{
Master of Arts \\ in \\ History
}

\title{
Thesis Committee: \\ Laura Robson, Chair \\ Linda Walton \\ James Grehan \\ Lindsay Benstead
}

Portland State University
2016 


\begin{abstract}
Scholarship on the modern history of the Middle East has undergone profound revision in the previous three decades or so. Many earlier perceptions, largely based on modernization theory, have been either contested or modified. However, the perception of the Egyptian ulama (the traditionally-educated, religious Muslim scholars) in academic scholarship remains largely affected by the legacy of hypotheses of the modernization theory. Old assumptions that the Egyptian ulama were submissive to political power and passive players incapable of accommodating, let alone of fathoming, conditions of the modern world, and who chose or were forced to retreat from this world, losing much, if not all, of their relevance and significance, still infuse the scholarly literature.

Making use of materials obtained from the Egyptian National Archives, this study offers an examination of modern legal reform in Egypt from the nineteenth century through the first part of the twentieth century with the ulama and their legal institutions in mind. As the findings of this study effectively illustrate, the Egyptian ulama were by no means submissive. Rather, they were patient. Far from being passive agents of the past, the Egyptian ulama were active participants who played a critical role in the building of modern Egypt. The ulama had at their disposal sustained social and moral influence, a long-standing position as community leaders, a reputation as defenders and representatives of Islam, the power to validate or invalidate the political
\end{abstract}


establishment by means of public and doctrinal legitimization, and the final authority over laws of family and personal status. Through these strengths, the ulama were able to influence the direction of change and to impact its scope and nature during transitional period that witnessed the making and remaking of modern Egypt.

Considering the nature of changes that they allowed to be introduced to the sharibased justice system and the ones they resisted, as well as their stance regarding social matters, the Egyptian ulama comprehended and recognized modernity as useful. Advanced techniques had to be embraced to strengthen state institutions. However, the ulama thwarted massive and sudden adoption of modernity's cultural elements, so that Egypt would not become a chaotic country and go astray. On the weight of their position as the ultimate authority over family law, the Egyptian ulama blocked rapid social change imposed from the top. Alterations to family law and the social structure were undertaken gradually and with a great deal of delicacy. Therefore, the long-standing social order was not suddenly destroyed and replaced with a new one. Instead, changes to the longstanding social structure were allowed to evolve slowly, while the core was largely preserved.

The ulama's far-reaching plan, which was realized in the long run, was to maintain Islam's position in modern Egypt as a guide and as the main source of legitimacy. As will be shown in this study, the history of the Egyptian ulama reveals not passivity, detachment, or submission but careful, and deliberate action. 


\section{Dedication}

This work is dedicated to the soul of my beloved brother, an innocent civilian killed on March 19, 2011, by Gaddafi's forces while trying to defend Benghazi. He dreamed of, and sacrificed his life for, a better future for Libya. One day, his dream will come true. 


\section{Acknowledgments}

I would like to express my gratitude for the great deal of support, understanding, and consideration that Portland State University's community has shown during difficult circumstances. This support has played a critical role in my academic progress. As a Libyan student, I acknowledge the contribution of Portland State University to my positive growth. I recognize PSU as a leading university that promotes and admires transcultural exchange-knowledge exchange-and cooperation on development. 


\section{Table of Contents}

$\begin{array}{lr}\text { Abstract } & \text { i } \\ & \\ \text { Dedication } & \text { iii }\end{array}$

Acknowledgments $\quad$ iv

\section{Chapter One}

The Egyptian Ulama and Modernity 1

Chapter Two

Legal Practice and Change in Egypt prior to 1897

Chapter Three

Transformation of the Shari Justice System 1855-1930

Chapter Four

The Egyptian Ulama in Modern Egypt: Custodians of Change 


\section{-Chapter One-}

\section{The Egyptian Ulama and Modernity}

The transformation of Muslim societies under the impact of modernity, or the contact with modern Europe, is an intriguing and vivid topic. Scholars and observers continue to explore key factors that played critical roles within the transformation. In the course of the eighteenth and nineteenth centuries, very powerful European states emerged. Through their strong militaries, these Western states pushed influence and power beyond their recognized borders. Muslims, who had previously thought of themselves as superior to Europeans, did not expect this development. Not only did Muslim armies suffer overwhelming defeats in the battlefield at the hands of the West, but parts of the Muslim world were also conquered and ruled by Western powers. Muslims came to recognize that the balance of power had shifted in Europe's favor. ${ }^{1}$

In response to European hegemony and the serious challenges it posed, a number of Muslim countries, such as the central Ottoman Empire and Egypt, initiated reform projects targeting mainly the army, economy, education, and other state agencies with the objective of enhancing their quality and performance. European technologies and techniques were adopted. Subsequently, Western culture and thought were felt to have started infiltrating almost every aspect of Muslim life. This perceived invasion, conceived as the outcome of both Western dominance and internal reform projects alike, generated 
various reform movements, as well as intellectual responses among Muslim scholars, almost everywhere in the Islamic world. ${ }^{2}$

Contact with Europe and the consequent borrowing from its resources established new currents of change at many levels in Muslim societies that were subject to this contact. However, how these Muslim societies changed as a result of this encounter with Europe has not been fully explored, nor has it been accurately evaluated and understood.

Typically, the Egyptian ulama and their institution, al-Ahzar, the chief center of Islamic and Arabic learning in the world, have been taken as representatives of elements of traditional Muslim society and of Islam. Conversely, secular political elites are seen as agents of change, creators of the modern state, patrons of modernity as a whole. Politically-initiated reform programs were expected to establish updated categories and institutions and to bring about the modernization of Muslim traditional society. To modernize effectively meant to weaken traditional elements and to strengthen and increase state control over all activities and spheres of society, particularly the religious arena. A principal goal of modernization is secularization; secularization is the appropriation by political entities of activities traditionally executed by religious agents. ${ }^{3}$

By and large, modernization is held to devitalize and eventually demolish the authority of the long-standing traditional order and to establish a modern authority, with the newly-created state spreading and consolidating its control over, and regulating, all activities performed within its borders. 
It has long been assumed, therefore, that in the face of rapid and relentless change introduced by modernity, the old-fashioned group, the ulama, became completely redundant. The ulama were presumed to neglect or disqualify new ideas, and to contribute almost nothing to the transformation of modern Muslim societies. Focusing largely on Pakistan, and to a lesser degree India, from the period of British rule until the present, Muhammad Qasim Zaman has effectively demonstrated that contrary to the aforementioned established assumptions, the ulama, their discourses, attitudes and institutions were indeed transformed by their encounter with modernity.

As Zaman shows, the ulama have addressed, and continue to address, challenges posed by modernity. Moreover, his research reveals that the ulama have not only successfully addressed and adapted to modern conditions, but have also maintained and enhanced their position in several contemporary Muslim societies, successfully: improving their influence, expanding their audience, contributing significantly to public discourses, defining such discourses, and playing important religious-political activist roles in contemporary Islam. ${ }^{4}$

In the past three decades or so, there has been substantial revision of historical analyses of the modern Middle East. Many old assumptions and premises have been challenged or altered. However, scholarly understanding of the ulama, particularly in Egypt in the modern world, has remained largely influenced by hypotheses of the modernization theory. Generally, scholars are particularly concerned with the emergence of Western-inspired trends in Egypt during the period in question. The presumable 
surface of secular proto-nationalist political ideologies and collective notions of belonging have been given a great deal of consideration. ${ }^{5}$ When examining Islamic responses to modernity, scholars tend to devote almost exclusive attention to the efforts of Muslim thinkers and Islamic movements seeking to reconcile Islamic classical thought and tradition with modern elements. ${ }^{6}$ While critically affecting the making and remaking of modern Egypt, the ulama's participation in this process has been either overlooked or misunderstood. Moreover, their ability to engage with change has been misconceived and underestimated.

Existing Scholarship on the Egyptian Ulama

In his 2010 well-researched monograph The Ulama, Politics, and the Public Sphere: An Egyptian Perspective, Meir Hatina attempts to boost scholarly knowledge of the ulama, especially the Egyptian one, and their relationship to the modern world. Hatina's excellent and comprehensive review of up-to-date scholarship on this topic ${ }^{7}$, his contribution to it, and the limitations of his study, serve as a useful starting point for outlining the premises of this research.

As Hatina observes, there are two main perspectives in the existing scholarship regarding the emergence of a new sociopolitical order in the Middle East during the nineteenth century and on the shifting status of the ulama during that time. The first point of view Hatina highlights is focused on the invasive character of the newly established 
modern state, which sought to bring under its control all activities executed within its borders. This point of view suggests the ulama became a mere bureaucratic part of this state. The new state extended its direct supervision over all, and claimed, the functions previously performed by the ulama, except for their jurisdiction over family and personal status laws. The second scholarly perspective described by Hatina stresses the impact of a group of intellectuals and activists who presented serious challenges to the religious authority of the ulama. The new intellectuals and activists were the product of the encounter with the Western culture, the spread of higher education, and the development of social schisms embodied in Islamic reformist and nationalist movements and the fundamentalism of the Muslim Brotherhood.

These reformist movements claimed to represent Islam and to promote its cause, while putting forth their own interpretation of the holy texts. In doing so, they were significantly supported by new legal structures separate from the shari-based system, widespread education, and print and communication culture. These new developments fostered the processes of democratization and personalization of religious knowledge, rendering the Islamic discourse more diverse than ever, with a range of spokesmen who competed for authority in the Muslim public sphere.

In Western historiography, the status of the ulama was negatively affected by these challenges. Islam remained a symbolic basis of protest, identity and legitimization, while the ulama fell behind in influence. Their role was confined to serving "as a rubber 
stamp for regime policy or as a tool to discredit local and foreign rivals."

The emergence of revolutionary regimes in the Middle East in the 1950s and 1960s followed by waves of Islamic resurgence in the 1970s further minimized the relevance of the ulama in examinations of this time period. In Western scholarship, Islamic protest was in essence a modern development. It was the modern, politicallyengaged Muslim intellectual who depended on activism and charisma more than knowledge, and whose attributes attracted the imagination of Western observers.

Two broadly-categorized exceptions to the model of the stagnation of the ulama and the deterioration of their significance and relevance were the shii ulama and the ulama of the semi-tribal milieu. The shii ulama had at their disposal independent financial assets along with doctrinal and juridical power, which rendered them autonomous from the political order and allowed their deliberate, active engagement in politics.

The semi-tribal ulama, particularly in peripheral areas such as the Arabian Peninsula and North Africa, enjoyed a great deal of influence because of their geographic distance from the urban regions. The semi-tribal ulama were respected and valued for their righteousness and piety. They established a close relationship with local dynasties and provided religious guidance, mediation, and conflict resolution in their communities. Moreover, the semi-tribal ulama initiated political movements aimed at reviving moral Islamic society. The semi-tribal ulama also led or supported the liberation movements that sought to obtain independence from the grasp of European colonialism. 
The urban, Sunni ulama, however, were frequently described as unvarying in nature, a submissive and withdrawn group on the defensive. Descriptions of the Sunni ulama as passive and intellectually non-innovative comprises a generalized perception by historians and social scientists that the ulama, as a whole, were traditionalists incapable of coping with the conditions of the modern world.

In Western historiography's excessive search for notable turning points in the complex sociopolitical history of the Middle East, the relevance of the ulama fell into obscurity. In 1983, Gabriel Baer argued "the establishment of a stable dynasty and a centralized bureaucracy deprived them [the ulama] of their former functions as legitimators and mediators. As a result, the ulama lost the rest of capability for any effective political activity." In 1988, Ira M. Lapidus asserted that the Ottoman and Egyptian ulama no longer had any influence on public policy. In 1995, Iftikhar Zaman observed that the colonial re-organization of society and the emergence of new social legal political orders resulted in the discontinuity in the function of the ulama. Iftikhar's observation was confirmed by John L. Esposito and John Voll, who in 2002 indicted the ulama's crisis of religious authority and transmission.

According to Hatina, quite recently, different conventional perceptions in the field of Middle Eastern studies informed by the modernization theory have been contested or modified. Perceptions challenged or altered included "the absence of a dynamic Muslim public sphere, the French conquest of Egypt in 1798 as heralding the start of the entry of local society into the modern era, the decline of the Ottoman Empire from the eighteenth 
century onward and its ineffective reform policy, the disharmony between Islam and nationalism, and the perception of nationalism as a new phenomenon in the Middle East with no historical or with no-cultural antecedents.” However, Hatina notes that “...the denigrating narrative regarding the status of the religious establishment has been largely preserved and has continued to foster supportive research."

In his research, Hatina pays close attention to late nineteenth- and early twentiethcentury Egypt with the objective of re-evaluating the status of the Sunni ulama during a period of modernization and nation building. He attempts to show that subservience to state power did not mean compulsory submission in all areas, and that the ulama's loss of their monopoly over the judicial, educational, and intellectual spheres did not mean marginalization. Hatina essentially supports historical insights offered by such renowned scholars as Richard Anton, Malika Zeghal, and Muhammad Qasim Zaman.

Richard Antoun's work is based on field work that demonstrates the ongoing influence of preachers and their sermons as cultural players in rural Jordan in contrast with other areas in the Muslim world. Malika Zeghal examines the outcome of the reform measures introduced into al-Azhar and the inclusion of modern secular sciences in its curriculum from 1961 onward. The reason for these steps at al-Azhar was to integrate the ulama into the modernizing sector of the state. The unexpected result of these reform measures was the emergence of a new form of modern Azhari graduate, which Zeghal calls peripheral ulama, who was of both religious and modern educational background. The new Azhari graduate was more associated with the Islamists in a greater degree than 
ever before, particularly in regard to restoring the sharia.

Moreover, according to Zeghal, the regime's increasing dependence on al-Azhar for public legitimacy along with the need to confront the challenges posed by the Islamists, enhanced al-Azhar's power and significantly expanded its engagement in the public life through the 1980s. Hatina endorses Zeghal's analyses. However, he points out that religious assertiveness in the public sphere was not a behavior limited to junior or peripheral ulama. Rather, this conduct can be observed among senior ulama as well, including the heads of the al-Azhar such as Abd al-Halim Mahmud (1973-78) and Jadd al-Jaqq (1982-96). In addition, the participation of the ulama in the public arena involved social and ethical matters too. This involvement was evident during the revolutionary order. For instance, the family-planning law backed by Gamal Abdel Nasser was not completely successful due to the resistance of the ulama to it. The ulama of al-Azhar also were active during the constitutional period (1923-52), standing against religious skepticism.

Even though Zeghal widened her historical analysis to include the active involvement of the ulama of al-Azhar in the intellectual debates in the 1930s and 1940s, she continues to regard the active political and intellectual role of al-Azhar in the late twentieth century in terms of "reemergence." Hatina points out that recent research conducted by Antoun, Zeghal, and Zaman regarding the influence of the ulama primarily covers the second half of the twentieth century. In his study, Hatina examines the period from the second half of the nineteenth century to the beginning of the twentieth century 
in order to provide more depth to insights of the revisionist research on the status of the Sunni ulama in the modern world.

In the course of the nineteenth century, Egypt was increasingly encountering a new ethical system that was both secular and Western. Hatina raises the question: How did this encounter impact the status of al-Azhar? Preeminent historians including H.A.R. Gibb, Afaf Lufti al Sayyid Marsot, Ira Lapidus, P.J Vatikiotis, Gabriel Baer, and Hava Lazarus-Yafeh have stressed al-Azhar's crisis and downfall in the aftermath of modernization and the institution of the modern state in Egypt. Other renowned scholars, such as Gilles Kepel, Olivier Roy, Emmanuel Sivan, Martin Kramer, and John Esposito, have either pointed to the shrinking role of al-Azhar in the social and political life in Egypt, or emphasized the challenges posed to its legal authority by the new intellectualmodernists and particularly Islamists. Hatina, however, suggests al-Azhar experienced relative rather than total crisis. While the Azharis were stripped of their political and economic resources and their monopoly as scholars, teachers, and intellectuals, they preserved a considerable degree of moral influence in society.

Hatina essentially offers a re-examination of the Urabi revolt. The Urabi Revolt was a popular uprising that took place in Egypt from 1879 to 1882 . The revolt was led by Ahmed Urabi, an Egyptian army general. Urabi and his followers sought to depose the Khedive (governor of Egypt and the Ottoman Sultan's viceroy) Tewfik Pasha (18521892) and to put an end to British and French influence over Egypt. As Hatina observes, the Urabi revolt was an historical event during which al-Azhar proved itself to be a force 
that could exert a powerful influence on the political and social life in Egypt. Reconsidering the Urabi episode, Hatina draws the following important conclusions and observations. At exactly the time that Western historiography regards as Egypt's discontinuity with the past and the breakdown of the religious establishment, namely, the second half of the nineteenth century, the ulama of al-Azhar showed communal vitality, including active political participation.

During the Urabi event, al-Azhar served as a vital and crucial site for the fight between Urabis' proponents and those who backed the Khedive over the allegiance of the people and legitimization from the Ottoman sultan. This development demonstrated alAzhar's role in shaping the collective consciousness. The Urabi episode also displayed a diversity of perspectives among the ulama of al-Azhar toward the Urabi movement. Most of the senior ulama took a quiet, low-profile position on political matters and maintained their loyalty to the Khedive, looking at him as "the legitimate authority and as a bulwark against anarchy and sedition among Muslims." However, their urge for calm was drowned out by the religious enthusiasm of an Azhari minority who were far from the modest scholarly asceticism of the senior ulama. For his part, the Ottoman sultan considered the stance of the senior ulama and disregarded that of the minority.

In the Urabi revolt, the Azhari ulama proved to be decisive in generating popular support for Urabi, making use of not only the power of the word, sermons and fatwa, "but also communal influence through the public offices they held, their associations, and their material assets, which swept along large numbers of followers." The professional and 
geographic reach of the ulama who backed Urabi was diverse. Notably, the cultural corpus of the ulama who backed Urabi was far more nuanced than described in the scholarship, which chiefly pays attention to such renowned Muslim thinkers as alAfghani, Abduh, and Nadim.

Among Urabi's supports were instructors, muftis, judges, imams, ashraf (a term refers to those who are in direct-blood line decedent from the Prophet Muhammad), and leaders of Sufi orders, performing as religious ministrants in major Egyptian cities, towns, and villages. They transformed Islamic tradition into the main opposition against the khedival regime and European presence. This gave the Utabist cause, militaristic in nature, a popular and pro-national flavor and granted it religious legitimacy.

Last, but not least, Hatina acutely observes that the moral authority of the Egyptian ulama was derived from a mixture of ideological, and more importantly, from sociological factors. In addition to moral resources, the ulama who supported Urabi were able obtain support through their social influence and their association with Sufi orders in both the urban and the rural social settings. Their scholarly prominence and charisma generated power. ${ }^{8}$

Certainly, Hatina's work is an important, welcomed contribution to the study of the ulama, specifically the Egyptian ulama. However, there are limitations to his work. While "contesting the paradigm" conventionally established about the Egyptian ulama, he uses the existing scholarly paradigm's unit of analysis, namely, al-Azhar, to challenge 
it. Besides al-Azhar, the Egyptian ulama presided over another highly-important legal institution: the Islamic shari courts. The Egyptian ulama sustained their legal authority over these courts until the second half of the twentieth century. Among many other things, the shari courts were decisive in determining the nature and the outcome of the modernization of Egypt. The old perceptions persist that the Egyptian ulama lost their judicial power as a result of modern legal reform, that they became effectively weak and submissive to state power, especially in the legal sphere. As an unverified academic story has been told, the Egyptian ulama were unable to deal with changes brought about by modernity. Last, but not least, the Egyptian political regimes, particularly in the course of the nineteenth century, depended heavily on the ulama not only for public legitimization, but doctrinal legitimization as well. This doctrinal legitimization consolidated the claim of rulers of Egypt of them being legitimate, independent Muslim rulers.

Focusing on nineteenth and the first half of the twentieth century Egypt, this study attempts to contribute to ongoing efforts to identify and clarify misconceptions and misunderstandings regarding the outcome of the interaction between modernity and the Egyptian ulama. It puts forth new information that enhances our understanding of this important topic. This study departs from the established paradigm about the Egyptian ulama. It does not take al-Azhar as the unit of analysis for evaluating how the Egyptian ulama dealt with the modern world and how their status was affected by the modernization of Egypt. Rather, it uses the shari courts, the most important legal institutions the Egyptian ulama controlled, as a frame of analysis. 
Misconceptions about the Egyptian Ulama Infused in the Historical Literature

According to the widely accepted account ${ }^{9}$, Egyptian modernization in the nineteenth century had devastating and lasting effects on the status and significance of the Egyptian ulama. The regime of Muhammad Ali (1805-49) was a major blow to the power of Egyptian ulama. Muhammad Ali's regime embarked on a centralization process, bringing under its supervision all major endowments and resources that had served as financial support for the ulama and their institutions for many years. As a result, under Muhammad Ali's regime the religious institutions, the wellspring of the vast influence the ulama possessed, entered a period of rapid decline. Subsequently, the ulama began to lose their source of power and influence. ${ }^{10}$

In addition to financial factors, Daniel Crecelius suggests another reason behind the declining influence of the Egyptian ulama: their approach to dealing with the modern world. According to Crecelius, the ulama failed to accommodate the changing conditions engendered by modernity. As he observes, "Throughout the nineteenth century, the corps of the ulama remained openly hostile to innovation of any form," preferring to sustain the status quo. From the early nineteenth century to the present, the ulama's stances and reactions to the challenges posed by modernity have been either opposition or withdrawal. $^{11}$

Crecelius anticipated that as long as modernization was a weak force in Egyptian 
society, the ulama's strategy of opposition and withdrawal would yield only short-term impact. In the long term, however, it was a self-defeating defense; it would only postpone, not halt, the penetration of modernization through all levels of society. The immediate outcome of this strategy was driving "the ulama into a physical and intellectual isolation that became almost suffocating."12 As result of the opposition and withdrawal strategy, the institutions belonging to the ulama remained largely unchanged. Even the efforts to reform these classical institutions, like those of Muhammad Abduh, ended in failure. ${ }^{13}$

Whereas Crecelius suggests that the decline of the ulama's power was due to Muhammad Ali's domination, Afaf Lutfi Al-Sayyid Marsot points out that the ulama at different times throughout history had been subdued by powerful rulers only to rise again. In her view, "it was the introduction of westernizing influences [in Egypt] that was the cause of their permanent decline as against a customary rise and fall from power. And the first effective Westernizing influences were introduced by Ali.",14

In a later work, Crecelius revises his views regarding the strategy the Egyptian ulama adopted to deal with modernity. However, he still sees their strategy as negative. Tracing the path of secularization in modern Egypt, Crecelius observes that Egyptian modernization only affected a small segment of society without completely disrupting traditional socioeconomic beliefs and institutions. ${ }^{15}$ With a supreme ruler, like Muhammad Ali the ulama were unable to block changes at the state level. However, their 
public opposition successfully confined reforms to a narrow governmental circle. ${ }^{16}$

The tendency toward institutional secularization set in motion by Muhammad Ali continued as the government enlarged its functions and centralized its authority. This expansion was not entirely disruptive to the pattern of traditional institutions "because much of the government's expansion was into areas of only marginal concern to the religious community or into new areas such as public health and sanitation." All the reform projects of Isma'il Pasha, Khedive from 1863 to 1879 , and those who came after him, have been successfully blocked or deflected by the "stubborn" defense the ulama have made. Though suffering gradual secularization in other areas, the ulama made successful stands to safeguard the autonomy and content of religious education, sharia law, and waqf (an Islamic endowment of property to be held in trust and used for a charitable or religious purpose). ${ }^{17}$

By and large, Crecelius concludes that the modernization project had transformed only a very small segment of urban Egyptian society. ${ }^{18}$ The very essence of a secular state appears to be missing in Egypt today, Crecelius observes, with traditional beliefs, practices, and values remain supreme among Egypt's teeming village population and among the majority of urban masses. ${ }^{19}$

Evidently, Crecelius holds that the Egyptian ulama, by thwarting alternations to the longstanding social order and preventing the spread of secularization to the social level, were effectively static, anti-change, and mere defenders of the old. Their role in the 
modern era was confined to halting progress. Crecelius' assessment, however, is incomplete. His conclusions, as he himself has noted, have proven to be more of anticipations than a historical account.

The present study primarily attempts to examine how the Egyptian ulama actually approached modernity. The assessment of the results of the interplay between the Egyptian ulama and modernity, and above all, of how the Egyptian ulama comprehended modernity and dealt with it, will be based on tangible examples of what really happened. The study also highlights the resources the Egyptian ulama had at their disposal which helped them to sustain their influences at many levels.

To avoid common misunderstandings and misconceptions resulting from the tendency to generalize when dealing with the ulama, we will first define the term ulama from an Egyptian perspective. Certain qualities that are particular to the Egyptian ulama and which distinguish them from their counterparts in the Islamic world will be highlighted. Many of these qualities have been observed and stressed by such scholars as Hanita, Crecelius, Marsot, and Wael Hallaq and have been cited throughout this study.

We will then explore how the Egyptian ulama functioned until the early nineteenth century. An emphasis will be placed on factors that are peculiar to Egypt. The significance of the Egyptian ulama, the essential sources of their influence, their approach to change, and their participation in the making of modern Egypt, all cannot be accurately evaluated and understood without first taking into account their role up to the beginning 
of modernization, a phase in the Egyptian history that witnessed a transition toward the adoption of political, legal, and economic ideas and techniques developed in modern Europe.

We will also consider the criteria scholars have used to evaluate the impact of modernity on the status of the ulama. We will illustrate how misunderstandings and misconceptions occur as a result of the current scholarly approach to the ulama and modernity topic. We will then explain how the reexamination of modern legal reform, keeping the ulama and their legal institutions in perspective, will significantly improve our understanding of this subject.

\section{The Egyptian Ulama}

Typically, the ulama, plural of alim (scholar) refers to Muslim religious scholars with a traditional educational background and various rankings in the Islamic religious sciences. In Egypt, an alim is a graduate of al-Azhar, the leading learning institution and a focal center of Islamic and religious and cultural life not only in Egypt, but in the whole Islamic world. Al-Azhar's focus is on the study and mastery of the sharia, or Islamic law, and Islamic tradition. As a graduate of al-Azhar, the alim is trained in the entire body of the sharia, including precepts of Quaran, hadith (reports describing the words, actions and habits of the Prophet Muhammad), fiqh (Islamic jurisprudence) and other Islamic religious and scientific areas. 
Until 1908, when the University of Cairo was founded, al-Azhar was the only school of higher education in Egypt. ${ }^{20}$ The ulama, therefore, were the most highlyeducated scholars in Egypt during this period. In 1876, al-Azhar hosted 10,872 students and had 325 shaykhs (teachers/instructors). ${ }^{21}$ We can infer that during the nineteenth and early twentieth centuries, there were thousands of ulama in Egypt. The ulama were involved in various activities in all spheres of society, occupying such religious, legal, educational, and social positions as imams (prayer leaders), qadis (judges), muftis (interpreters or expounders of Islamic law), and teachers.

Ulama is an umbrella term, a complex and rather problematic one. At the group level, and the term ulama covers a spectrum of various tendencies, perspectives and personalities of religious scholars ranging from what might be referred to as extremely conservative on one end to very liberal on the other. The ulama were never represented by one perspective. They were in constant debate with each other as well as with others, within and outside their circle, regarding political, social, economic, legal, religious, and all matters. Their attitude toward a given issue varied from one alim or an ulama faction to another and was in constant flux.

There was a hierarchy/rank within the ulama group with various grades/levels from the highest to the lowest mainly determined by level of knowledge, contributions to it, social status, wealth, occupation, type of activism...etc. In terms of association and integrity/status, there were ulama closely associated with the political establishment. Most of the ulama of this type were regarded, at least in the eyes of the masses as well as 
other ulama, as having compromised their integrity, serving as a tool at the hands of political power, which was seen as corrupted and mostly, if not totally, concerned with worldly matters. On the other hand, there were ulama who did not hold any official posts in the government and were active in the public sphere. This ulama category may refer to as independent or peripheral ulama.

When speaking of the ulama in this study, we refer to those who tended to fall in the middle of the aforementioned spectrum. These ulama were active religious scholars who were generally respected, trusted, and recognized by the masses and politicians as community leaders dedicated to serving the sharia and pursuing the interests and advancement of the Muslim community. Their credibility and integrity were firmly established. Their stance was characterized by modesty. They tended to draw on the ulama's long, rich tradition and history to effectively and wisely deal with changing circumstances and to maintain stability and order. While they may not have constituted a majority, they were so influential that they could affect the stance and attitude of the entire group.

In the wider Islamic world, the perspectives, attitudes, responses, positions and degree of influence of each ulama group belonging to a particular Muslim land varied. They were shaped by specific local and outside conditions and circumstances, as well as varieties of historical experience. This diversity among the ulama is often obscured by the tendency to generalize, namely, drawing broad conclusions about the ulama based on the observation of one case, and extending these conclusions to other cases. The following 
example shows how expanding a limited, non-representative set of observations to the larger group results in misrepresentation. For the conservative ulama in the central Ottoman Empire (now Turkey), the destruction of the janissaries (members of an elite corps in the standing Ottoman army) in 1826 constituted a major blow to their influence. The disappearance of the janissaries meant that there would no longer be a force able to back the ulama and protect their interests. As a result, the ulama became effectively weak; political forces were able to introduce dramatic alterations at all levels. ${ }^{22}$ This was never the case in Egypt as we shall see.

The present study is sensitive to the particularity of the Egyptian circumstance, stressing Egypt's distinctive experience with modernity. The peculiar position of the Egyptian ulama in society as well as their unique historical experience will be taken into account when assessing how the Egyptian ulama interacted with modernity.

The Role of the Egyptian Ulama before the Start of Modernization As Crecelius observes, in pre-modern times, sharia served as a life guide. The ideal Muslim society was supposed to follow the rules and ideals of the sharia as closely as possible. The ulama, devoting their efforts to the mastery of the sharia, were responsible for explaining God's commands and prescriptions for the community. Muslim rulers were responsible for enforcing the rules of the sharia. A just Muslim ruler was to seek advice from the ulama regarding all matters of the law. In 
theory, the political establishment was subordinate to the sharia. ${ }^{23}$ The ulama conceived themselves as advisers, not rulers. This understanding has marked the relationship between religion and the state until the present day.

In pre-modern times, the ulama legitimized political power; they were the final authority on social conduct; they even molded economic policy. The ulama continued to act as the ultimate authority of what was pleasing (legal) or reprehensive (illegal). They were often forced to compromise in the face of the superior power of their rulers. The ulama nevertheless continued to decide how law and custom could accommodate innovation or depart from traditional ideals.

In pre-modern times the unity between religion and the state was sustained no matter how large the political gap between the ulama and the rulers. No matter how far society might stray from its ideals, the community remained divinely guided as long as the rulers recognized the superiority of the sharia and gained the approval of the ulama for their actions. ${ }^{24}$

For her part, Afaf Lufti al Sayyid Marsot examines how the ulama functioned before the nineteenth century from a different angle. She pays close attention to the intricate relationship between the ulama and Muslim ruling elite on one hand, and the dynamic between these two groups and the masses on the other. Marsot also shows how both the ulama and Muslim ruling elites worked together. She draws an important distinction between the meaning of and exercise of power and authority and she explains 
how both groups negotiated power.

As Marsot notes, there were two major groups admitted within Muslim society who had authority over the people: the military ruling elite and the ulama. While the authority of the military was derived from the use of coercive force, the authority of the ulama originated from the use of moral and religious sanctions. The military was in charge of the administration and ruling of the state, whereas the ulama, being the guardians of religion, were in charge of the intellectual and social life and the law and its application.

Both groups learned to cooperate, but shortly thereafter the military used its power of coercion to impose its will upon the religious authorities. The ulama developed a tradition of submission to the established political authority whenever they saw they could not do otherwise. However, the ulama were indispensable to the ruler. Muslim rulers used the ulama to legitimize their actions in relation to the community and to help them rule the people. For a society dominated by religion and tradition, the moral influence of the ulama was significant.

Turning to Egypt, Marsot observes that in this Muslim country and under the later Mamluk period (Mamluk rule began in the thirteenth century and ended in 1517 with the accession of the Ottoman Empire) the ulama achieved a close, distinctive relationship with the ruling group and became the natural leaders of the people. Under the Mamluks in Egypt, the ulama served as a liaison between the rulers and the population at 
large. The Egyptian ulama held a special position because of the Mamluk system of rule; this special position was reinforced because the rulers and ruled constituted different ethnic and linguistic units. There was a gap between the Mamluks and the Egyptians. The ulama helped to bridge this gap by serving as intermediaries.

The influence the ulama had over the people was one of main sources of their power in Egypt. Only the ulama were able to sustain peace without a show of force. The Mamluks respected the ulama not only because of their religious orientation but also because they knew that the ulama controlled the people and could both rouse and restrain them. It was this dual role of rabble-rousers and peace-makers that was the source of the ulama's political power in Egypt.

The ulama's role as de facto leaders gained in importance during the French occupation (1798-1801). When Napoleon Bonaparte occupied Egypt, he ruled it through the ulama, whom he recognized as the natural leaders of the Egyptian people. The period of anarchy that followed the evacuation of the French forces created an opportunity for the ulama to do more than act as mediators between fighting factions. The rise of Muhammad Ali to power in 1805 was to some degree due to a stand the Egyptian ulama took on his behalf. Since they were not used to exercising power directly, after Ali was enfranchised, the ulama went back to their college. ${ }^{25}$

In sum, the Egyptian ulama had historically functioned as a religious, legal, political, moral, and social force at once. ${ }^{26}$ Crecelius, however, has examined the 
Egyptian ulama in relation to modernity as mainly a political power. For him, the regime of Muhammad Ali, which disregarded the Egyptian ulama, refused to take their advice, and dominated them, started the process that eventually led to the destruction of their economic and political powers in Egypt. With the Nasserist regime (1956-1970) nationalizing the waqfs, reforming al-Azhar itself, and obtaining the right to decide its leadership, the decline of the power of the Egyptian ulama was assured and completed.

Unexpectedly, less than a decade later, the ulama re-emerged on the Egyptian scene as a notable political force. In the course of the 1980s, radical Islamic groups began to surface in Egypt, challenging the legitimacy of the Egyptian regimes, and resorting to violence to bring about political change. Only the ulama were able to confront these groups. As the reliance of the political power on the ulama significantly increased, the role of the ulama in shaping and impacting state policies and decisions was heightened as well. The emergence of radical Islam resulted in the revival of the role of the Egyptian ulama as power brokers and legitimizers of political power. ${ }^{27}$ In the long run, therefore, the Egyptian ulama restored their political influence.

Far from weakening the ulama, modernization, which was justified in Islamic terms as will be shown in due course, effectively reinforced the position of Islam as the main source of legitimacy. Given that the Egyptian society remained dominated by Islam; that the Egyptian ulama maintained their longstanding position as the sole voice of Islam and community leaders (during the nineteenth and early twentieth centuries as least); that the legitimacy of the political power was fragile, constantly contested and challenged on 
Islamic grounds; the Egyptian ulama were always called upon to defend and/or confirm the legitimacy of the political order. In addition, and perhaps more importantly, modernization did not drain the greatest significance of the Egyptian ulama: their social influence.

Social influence is understood as change in an individual's thoughts, feelings, attitudes, or behaviors resulting from interaction with another person or group. Social influence guides the steps by which people make real modifications to their behaviors as a result of interaction with those who are seen to be similar, desirable, or expert. Power is the ability to compel or coerce by manipulating the outcomes while authority is power that is believed to be legitimate, not coercive, by the persons who are subject to it. ${ }^{28}$

Historically, the Egyptian ulama were firmly-established as the spiritual and genuine leaders of the masses, experts in the sharia, legitimizers of political power, and the ultimate authority of what was satisfying/legal or reprehensive/illegal. Their leadership was earned by a long-standing integrity and a reputation of being "the ideal of piety, rectitude and fine education. Their very profession as Guardians of Religion, experts in religious law and exemplars of virtuous Muslim lifestyle made them not only the most genuine representatives of the masses but also the true 'heirs of the Prophet,' as one Prophetic report came to attest." 29

In the aftermath of Egyptian modernization, the political order stayed mostly away from social affairs and the civic life. The ulama, and not the ruler, were largely in 
charge of family law and the civil life at large. The shari court, presided over by the Egyptian ulama, preserved an identity sufficiently separate from the central government, as well as a reputation for justice that allowed it to remain a popular institution. Many Egyptians looked at the shari court their institution — as a place to which they could go for redress. ${ }^{30}$

As this study stresses, the influence of the Egyptian ulama served as the crucial source of validating authority. The authority of the Egyptian ulama was mainly sustained by social influence and ought to be seen as a manifestation of it. On the weight of their social influence, the Egyptian ulama continued to act as custodians of change and guardians of Muslim culture. Before moving on to discuss how the examination of modern legal reform will help to construct a clear picture of how the Egyptian ulama coped with changes introduced by modernity, it might be useful to explain how the Egyptian ulama impacted political power through the exercise of moral/social influence. 
The Egyptian Ulama as a Moral/Social Force

The Egyptian ulama enjoyed a high level of status in society not only because of their reputation as pious religious scholars devoted to serving the sharia, Islam, and the advancement of the Muslim community, but also because they lacked interest in the exercise of power. As far as the ulama were concerned, their role was not to rule, but to guide, to enlighten, to advise, and to safeguard and ensure the pre-eminent position of the sharia/Islam in society.

In a society dominated by Islam, the voice of the Egyptian ulama, who claimed to speak in the name of the sharia, was so powerful and influential that the Egyptian ulama were the only authority capable of maintaining peace and order without a show of force, and of mobilizing the masses for actions against political power. Muslim political elites, on the other hand, were associated with the use of coercion and regarded by the public as being opportunists mostly, if not totally, concerned with worldly matters. Infamous and distrusted, the ruling class was distanced from and disconnected with the people they ruled.

The ulama, by maintaining, however cautiously, a close connection with the political elites on one side and an intimate relationship with masses on the other, were able to bridge the gap between the ruled and rulers, serving as a mediator between them. The ulama cooperated with political power as long as the political elite recognized the superiority of the sharia in society and polity and sought the ulama's advice and approval 
regarding state policies. Since the legitimacy of political power was fragile, the support of the ulama to sustain it was crucial.

The moral influence of the ulama over political power was positive and negative. 31 The ulama could impact the regime positively by cooperating with it and endorsing its policies. Here, the ulama could play a direct role in shaping the decisionmaking process. The ulama could negatively influence political power by distancing themselves from it and disapproving its projects and agendas. In this situation, the regime might refrain from pursuing its plans, or might instead go against the advice of the ulama, which could damage its reputation and jeopardize its legitimacy. A regime that dismissed the advice of the ulama might well find its plans self-limited.

In the face of powerful rulers who ignored them, the Egyptian ulama were patient, not submissive. Concessions, at times considerable, could be made. Simultaneously, the ulama would define when the ruler had crossed the line, departed from the ideal, and upset and violated boundaries of the sharia. Depending on the extent of the deviation from the ideal and violation of the sharia, as well as the circumstances, the ulama's reaction would range from private or public disapproval of the regime's programs and actions to mobilization of the masses in opposition to the regime, stripping it of legitimacy. The latter option was rare; it was a last resort, a risk only taken if success was almost guaranteed. The Egyptian ulama continued to influence political decisions even if they might not be visible on the scene. 
The Ulama and Modern Legal Reform in Egypt

The examination of how modern legal reform was carried out in Egypt and the impact of this reform on the Egyptian ulama and their legal institutions, the shari courts, offers invaluable insights on how the Egyptian ulama understood modernity and dealt with it. An examination of modern legal reform also provides concrete details that allow us to more accurately evaluate the outcome of the interaction between the Egyptian ulama and modernity.

As this research shows, in the nineteenth and early twentieth centuries, the Egyptian ulama continued to legitimize political power and served as the final authority of social conduct and the ultimate authority of what was permissible or not. To be sure, in modern Egypt, the ulama maintained their role as custodians of change and guardians of Muslim culture. Egypt remained guided by the spirit of the sharia. Egyptian political elites continued to acknowledge the superiority of the sharia and sought the approval of the ulama for important state policies. Furthermore, and perhaps more importantly, the present study demonstrates that the Egyptian ulama and the legal institutions belonging to them, the shari courts, had indeed undergone profound changes a result of their experience with modernity.

Contrary to the established believes, this research clarifies that modernization in general and modern legal reform in particular in Egypt did not affect the Egyptian ulama as negatively as is assumed. In fact, the ulama helped to justify modern legal reform and 
were, for the most part, in charge of it. As we will see, in the long run, modernization did not weaken Islam's leading position in society. Rather, it consolidated the role of Islam as the most important source of legitimacy.

That the Egyptian regimes were able to make changes at the state level with little resistance from the ulama can be attributed to certain factors that were particular to Egypt. Unlike many other Muslim countries, Egypt was ruled and continued to be ruled by Muslim regimes. Egypt, therefore, did not experience the loss of Muslim rule like latenineteenth century India, where the loss of Muslim rule to the colonial one was conceived of as a serious threat to Muslim identity in that nation, hence, demanding an urgent response.

As Michael Gasper points out in his book The Power of Representation: Publics, Peasants, and Islam in Egypt, Egypt remained, however symbolically, a part of the Ottoman Empire until 1904. According to Gasper, Egypt was never a formal colony of any specific Western power. Even though the British ruled Egypt after 1882, several European states played an indirect role in Egyptian affairs that impacted the ruling and implementation of European authority's decisions. Moreover, the agent of the many changes Egypt experienced, typically dictated by colonial powers in other countries, was a Muslim ruler, namely, Muhammad Ali. Attempting to establish a state for his own family, Ali introduced a number of administrative, bureaucratic, and economic reforms and policies that propelled the formation of modern Egypt. He created a big modernized army, placed the cornerstones of a modern bureaucratic state and founded new 
educational centers. ${ }^{32}$ Generally, the Egyptian political elites had shown formal, public respect for the sharia/Islam and acknowledged, indeed stressed its crucial role and leading position both in society and polity. All Egyptian regimes either sought the approval of the ulama for actions or explained reforms in Islamic terms.

Notably, modern legal reform in Egypt was largely made in areas such as criminal law in which the state had historically established solid footing and presence and enjoyed almost exclusive authority over these legal matters. Long before modern legal reform was initiated, criminal justice in Egypt was mainly administered by a hierarchy of state legal councils. The ulama were and continued to be in the aftermath of modern legal reform in charge of general civil law and family law. ${ }^{33}$

Examining the Egyptian legal system during the largely unstudied first threequarters of the nineteenth century, namely, before the establishment of the Mixed Courts, experts Rudolph Peters, Jan Goldberg, and Khaled Fahmy have revealed that the purpose of modern legal reform in this country was not to replace the traditional sharia-based legal system with a Western one, nor did it intend to dismiss the ulama from the legal domain. Rather, the objective was to supplement sharia and to develop a legal structure that would better serve the needs of the newly-created modern Egyptian state. ${ }^{34}$

As Tallal Asad observes, what especially distinguishes the modern state from that of earlier times is that while previously laws were a means of delivering justice, modern law is used as a tool to obtain control, to "enable or disable the population," and as a 
means of reorganization. ${ }^{35}$ In this context, Timothy Mitchell rightly conceives nineteenth century legal and educational change in Egypt as the product of "enframing," a conceptual colonization that replaces an old "invisible" order with a new system that renders its components and inhabitants visible and quantifiable. ${ }^{36}$

With the creation of the modern state in Egypt, all activities that had been hidden from the eyes of the government were to be brought under the direct control and supervision of the state. What was to follow directly on this transparency would be the reshaping and reorganizing of these activities, making their components visible and quantifiable.

The Egyptian ulama limited the extent and pace of the change desired by the state. The longstanding social order was to be preserved. Alterations were to be gradually to follow and carefully introduced. The Egyptian political elites did not dare to upset the process of change as it was delineated by the Egyptian ulama not only because of the ulama's social/moral influence over them, but also because the ulama legitimized Egypt's political authority and, by implication, modern legal reform itself.

As recent studies on the legal history of Egypt have disclosed, legal reform in Egypt served as an effective weapon in the struggle of Egyptian rulers to secure Egyptian independence from the Ottoman Empire. While nominally part of the Ottoman Empire, Egypt developed its own distinctive legal system, enacting laws and adopting and developing new legal procedures that suited Egyptian circumstance. By doing so, Egypt 
acted as a completely independent state. ${ }^{37}$ As will be shown in this study, rulers of Egypt had obtained certain legal privileges from the Ottoman government that enabled them to manage single-handedly most of legal affairs of Egypt. These legal privileges were not enough. Egyptian leaders worked to secure legitimacy through Islamic right testifying to the fact they were absolute, legitimate, independent Muslim rulers. Egyptian ulama provided this validation.

The examination of modern legal reform, bearing the ulama and the shari justice system in mind, offers insights into how the Egyptian ulama conceived of modernity and how they dealt with it. The ulama appear to have understood modernity as providing useful advances in technology and techniques, but rejected it as a culture. The ulama seem to have allowed modern elements to be introduced at the state level, but resisted attempts to introduce rapid social alterations.

For the ulama, social change was to be approached piecemeal and cautiously so that the longstanding social order would not suddenly collapse. The ulama defended their position as the final authority over the shari courts, which served as the last fortifications of Islamic law and as the guardians of Islamic values and culture. Changes were introduced to the family law later, but it was a gradual process and was undertaken with a great deal of delicacy. ${ }^{38}$

This study consists of three additional chapters. Chapter two provides background for the subsequent chapters. It sheds light on important aspects of legal practice in Egypt 
during the seventeenth and eighteenth centuries. Special attention is given to the function, operating procedures, role, scope of authority, and jurisdiction of the Muslim judge and his shari court. In short, chapter two illustrates how the shari courts used to work. Understanding how the traditional legal system operated in Egypt in the seventeenth and eighteenth centuries, while highlighting the most important aspects of the shari system will help the reader recognize the specific changes that this system began to undergo during the nineteenth century.

The second section of chapter two focuses on factors leading to the creation of secular legal bodies in Egypt, operating side-by-side with the traditional shari legal system. The establishment of secular legal bodies modeled on Western designs, were intended to provide the government with more effective means of controlling and regulating certain activities. However, the creation of these bodies and adoption of Western legal codes and procedures were justified in Islamic terms. Modern legal reform was not imposed. Certain legal rights that the sharia gave to Muslim ruler were amended. These rights permitted the ruler to deal single-handedly with particular legal matters without consulting the ulama.

Concentrating on the period from 1855 through 1930, chapter three traces the process by which the Egyptian government brought the shari legal system under its direct supervision. Chapter three also discusses modifications introduced into the shari system that rendered it compatible with modern legal and administrative parameters. These modifications enabled the shari courts to continue to exist until the second half of the 
twentieth century. Two factors that facilitated the transformation of the shari legal system are highlighted: the power of print, and the efforts of distinguished Egyptian thinkers and reformers, such as Mohamed Abdah.

Essentially, chapter three demonstrates that both the shari courts and ulama were not isolated from a world that was rapidly changing around them as has been assumed. In fact, the shari courts and the ulama were influenced, transformed by, and even contributed to, the currents of change that Egypt witnessed starting from the early nineteenth century and continuing onward into the twentieth century.

Chapter four intends to show that even though the Egyptian government brought the shari courts and personnel under its direct control and supervision, the ulama were able to maintain their exclusive authority over the shari system. More specifically, this chapter presents evidence showing that despite the extension of modern state control over the shari justice system, the ulama - mainly through the weight of their social influence and public religious assertiveness - could and did set the of the shari court's transformation. While allowing certain modern techniques to be introduced to the outer structure of the shari legal system, the ulama successfully defended their epistemic authority, preventing any modification or alteration of the family law without their approval.

Chapter four also contributes to ongoing discussions regarding the issue of how command of law was transferred from the hands of the ulama to those of the state, one 
silent outcome of modern legal reform. Modern legal reform resulted in the emergence of the infamous and distrusted political class as bearers of legal authority. This development is responsible for the legal and political crisis in the contemporary Islamic world.

It has been suggested that the transfer of the command of law to the hands of the state was "sudden," that it was achieved by means of "force" and "coercion." Additionally, it is believed that through modern legal reform, the ulama became disabled, effectively weakened and left bankrupt. Allegedly, the ulama either chose or were forced to step aside and withdraw from a new reality they were incapable of handling. These conclusions do not correspond with the Egyptian situation/experience as this study discloses.

Chapter two shows that the Egyptian government, by expanding legal rights that the sharia granted to Muslim rulers, was able to make fundamental changes to the existing legal system, introducing Western-inspired legal entities and concepts.

As an extension of chapter two, chapter four further demonstrates that the Egyptian government justified its new role as a legislator and accounted for modern legal reform from a shari perspective: that the ruler was the sole source of legal authority. Stated differently, the evidence at hand shows clearly that the Egyptian government was acting as legislator and carrier of legal authority under a cover of legitimacy, and that this cover came from within the Egyptian ulama circles.

One important element this chapter tries to clarify: The apparent vulnerability of 
the modern state, its detachment and isolation from, its subjects, was what made, and continued to make, the ulama indispensable to the modern state.

As the two important historical events examined in chapter four clearly demonstrate, the influence of the ulama in the public sphere remained strong. Religious assertiveness in the public sphere served, when necessary, as an effective and powerful tool through which the ulama could not only force the state to adjust to the ulama's mindset, but could also stress their epistemic authority. In this capacity, the continuation of the ulama's social influence is a clear manifestation of two facts. First, the status of the ulama as "Guardians of Religion, experts in religious law, exemplars of virtuous Muslim lifestyle, and the most genuine representatives of the masses" remained largely intact and outlived the modernization program. Second, the ulama, based on their influence in the public sphere, continued to serve as custodians of change, and were able to restore other influences over time.

By and large, in the face of powerful political elites inspired and influenced by modernity and committed to make Egypt a part of the modern world, the Egyptian ulama managed to preserve Islam as a major force in Egypt's political and social life. 
Notes on Terminology and Sources

The term traditional is used to refer to ideas, practices, and institutions that had been in development for a long period of time and were in existence and operation in Egypt at the beginning of the nineteenth century. The term shari is used as an adjective, a designator of the sharia. It might be translated as religions, Islamic, and legal.

The term Egyptian modern state, is used to refer to the state created in Egypt in the nineteenth century. Strictly speaking, the terms modern state or modern nation-state may not be fully applicable to the type of state founded in Egypt. The modem state in Egypt did not work the same way a modern Western state operated. Among other things, the modern state in Egypt stayed mostly away from social affairs and the public sphere. The Egyptian ulama, and not the ruler, were largely in charge of family law and the civil life.

In covering important aspects of legal practice in Egypt before the turn of the nineteenth century, chapter two depends on works of Galal H. el-Nahal and Muhammad Nur Farahat (in Arabic). Both scholars are pioneers in this area of research. Utilizing court registers preserved in the Egyptian National Archives (Dar al-Wathaiq alQawmiyya), Nahal and Farahat have shed light on several important aspects of legal practice in Egypt during the seventeenth and eighteenth centuries. With respect to the nineteenth century, the chapter relies on the most recent research conducted by such experts in legal history of Egypt as Khaled Fahmy and Rudolph Peters. 
It should be pointed out that the legal history of Egypt is still very much in development. There are only a limited number of studies dealing with the subject. Among other things, chapter three and four can be seen as a contribution to this developing area of Egypt's history. Both chapters three and four depend on contemporary archival materials obtained from the Egyptian National Archives such as governmental documents (e.g official meetings and decrees), newspapers, and contemporary texts of enacted laws. Chapter three makes use of a significant report written by Muhammad Abduh on the shari courts. Apparently, this report has never been consulted, even though it offers valuable insights on the conditions and operations of the shari justice system in the late nineteenth century. In addition, as will be shown in chapter three, this report played a critical role in paving the way for profound changes to the shari justice system.

Chapter four also reveals a number of highly relevant archival documents, making available materials that disclose the Egyptian government's complex narrative, a narrative in which the government justified how Egypt's political elite emerged as legislators and commanders of the law in the early twentieth century. 
Notes to Chapter One

1. For broad perspectives on this development, see Benedict R O'G Anderson, Imagined Communities: Reflections on the Origin and Spread of Nationalism ( London and New York: Verso, 2006); John J. Donohue and John L. Esposito, Islam in Transition: Muslim Perspectives ( New York: Oxford University Press, 2007); Esposito, The Oxford of Islam ( New York: Oxford University Press, 1999); James L. Gelvin and Nile Green, Global Muslims in the Age of Steam and Print (Berkeley: University of California Press, 2014); and Albert Hourani, Arabic Thought in the Liberal Age, 1798-1939 ( New York: Cambridge University Press, 1983).

2. For detailed information about the Muslim response to modernity, see Nasr Hamid Abu Zayd, Reformation of Islamic Thought: A Critical Historical Analysis (Amsterdam: Amsterdam University, 2006); John Cooper, Ronald L. Nettler, and Mohamed Mahmoud, Islam and Modernity: Muslim Intellectuals Respond (London: Tauris, 2000); John Obert Voll, Islam, Continuity, and Change in the Modern World (Syracuse: Syracuse University Press: 1994); Richard L. Chamders, ed, Beginnings of Modernization in the Middle East: The Nineteenth Century (Chicago: University of Chicago Press, 1968); Albert Hourani, A History of the Arab Peoples (Cambridge, Mass: Belknap Press of Harvard University Press, 1991) and Arabic Thought; John L. Esposito and John Obert Voll, Makers of Contemporary Islam (New York: Oxford University Press, 2001); Donohue and Esposito, Islam in Transition; Esposito, The Oxford of Islam; and Gelvin 
and Green, Global Muslims.

3. The Eurocentric perspective is highlighted by Khaled Fahmy in "The Anatomy of Justice: Forensic Medicine and Criminal Law in Nineteenth-Century Egypt," Islamic Law and Society, Vol. 6 (1999), 224-31.

4. Muhammad Qasim Zaman, The Ulama in Contemporary Islam: Custodians of Change (Princeton: Princeton University Press, 2010).

5. Michael Gasper, The Power of Representation: Publics, Peasants, and Islam in Egypt, (Palo Alto: Stanford University Press, 2008), 219.

6. Zaman, The Ulama, 1-10.

7. Meir Hatina, Ulama, Politics, and the Public Sphere: An Egyptian Perspective (Salt Lake City: University of Utah Press, 2010), 4-9.

8. Ibid, 43-81, 171-75.

9. This narrative, or more accurately, perception, is mainly established by Daniel Crecelius and Afaf Lutfi Al-Sayyid Marsot and it still infuses academic scholarship. See for example Hatina, Ulama Politics, 28-29, and Wael B. Hallaq, "Juristic Authority vs. State Power: The Legal Crises of Modern Islam," Journal of Law and Religion, Vol. 19, No. 2 (2004), 254-57.

10. See Daniel Crecelius, "Nonideological Responses of the Egyptian Ulama to Modernization," in Scholars, Saints, and Sufis; Muslim Religious Institutions in the 
Middle East Since 1500, ed. Nikki R. Keddie (Berkeley: University of California Press, 1972); Crecelius, "The Course of Secularization in Modern Egypt," in Islam and Development: Religion and Sociopolitical Change ed. John Esposito and Hossein Askari (Syracuse: Syracuse University Press, 1980).

11. Crecelius, "Nonideological Responses," 188.

12. Ibid, 184-88.

13.Ibid, 167.

14. Afaf Lutfi Al-Sayyid Marsot, "The Role of the Ulama in Egypt During the Early Nineteenth Century," in Political and Social Change in Modern Egypt: Historical Studies from the Ottoman Conquest to the United Arab Republic, ed P. M. Holt (London: University of London, 1968) 277.

15. Crecelius, "The Course of Secularization," 75.

16. Ibid, 76 .

17. Ibid, 78.

18. Ibid, 81 .

19. Ibid, 81 .

20.Juan E. Campo, Encyclopedia of Islam, (New York: Facts On File, 2009) 80.

21. Donald Malcolm Reid, "Al.Azhar," The Oxford Encyclopedia of the Islamic World. Oxford Islamic Studies Online, 
http://www.oxfordislamicstudies.com/article/opr/t236/e0091.

22. Voll, Islam, Continuity, and Change, 88 .

23. Crecelius, "The Course of Secularization," 69. For more information about the role of the ulama before the turn of the nineteenth century, see Carl F. Petry, The Civilian Elite of Cairo in the Later Middle Ages (Princeton: Princeton University Press, 1981); Jonathan Porter Berkey, The Formation of Islam: Religion and Society in the Near East, 600-1800 (New York: Cambridge University Press, 2003); Michael Chamberlain, Knowledge and Social Practice in Medieval Damascus (New York: Cambridge University Press, 1994); and Ira Marvin Lapidus, A History of Islamic Societies (New York: Cambridge University Press, 2014).

24. Crecelius, "The Course of Secularization," 67-70.

25. Marsot, "The Role of the Ulama," 264-70.

26. Hallaq, "Juristic Authority,” 246. Hallaq does not highlight the ulama as a political force.

27. Malika Zeghal, "Religion, and Politics in Egypt: the Ulema of al-Azhar, Radical Islam, and the State (1952-94)," International Journal of Middle East Studies 31 (1999) 371-399; Tamir Mosustafa, "Conflict and Cooperation between the State and Religious Institutions in Contemporary Egypt," International Journal of Middle East Studies 32 (2000), 3-22; Steven Barraclough, "al-Azhar: Between the Government and the Islamists," Middle East Journal 52 (1998), 236-249. 
28. Lisa Slattery Rashotte, "Social Influence," The Concise Blackwell Encyclopedia of Sociology, ed George Ritzer and J. Michael Ryan (Oxford: Blackwell Publishing, 2011); Rashotte, “Social Influence.” In The Blackwell Encyclopedia of Sociology (2007).

29. Hallaq. "Juristic Authority," 252.

30. Judith Tucker, Women in Nineteenth-Century Egypt (Cambridge: Cambridge University Press, 1985), 14.

31. Crecelius, "Nonideological," 183, observing the Egyptian ulama's exercise of negative influence.

32. Gasper, The Power of Representation, 218.

33. Deniz Kandiyoti, Women, Islam, and the State, 201, Dawoud el Alami and Doreen Hinchcliffe, Islamic Marriage 3, 228.

34. Rudolph Peters, "Islamic and secular criminal law in 19th century Egypt: the role and function of the qadi," Islamic Law and Society, 4 (1997), 70-90, and "For his Correction and as a Deterrent Example for Others: Mehmed 'Ali's First Criminal Legislation (1829-1830)," Islamic Law and Society, Vol.6 (1999), 164-193; Jan Goldberg "On the Origins of the Majdlis al-Tujjdr in Mid-Nineteenth Century Egypt," Islamic Law and Society, Vol. 6 (1999), 193-223; and Khaled Fahmy, "The Anatomy of Justice."

35. Talal Asad, "Conscripts of Western Civilization," in Dialectical Anthropology: Essays in Honor of Stanley Diamond, ed Christine W. Gailey (Gainesville: University of 
Florida Press, 1992) 333-51.

36. Timothy Mitchell, Colonising Egypt (Berkeley: University of California Press 1991).

37. Rudolph Peters, "Islamic and secular criminal law," and "For his Correction"; Jan Goldberg "On the Origins of the Majdlis"; and Khaled Fahmy, "The Anatomy of Justice."

38. On the gradual reform of family law in Egypt, see Fauzi M. Najjar, "Egypt's Laws of Personal Status," Arab Studies Quarterly Vol. 10, No. 3, (Summer 1988) 319-344; Judith Tucker, Women in Nineteenth-Century Egypt; Deniz Kandiyoti, Women, Islam, and the State (Philadelphia: Temple University Press: 1991); Dawoud el Alami and Doreen Hinchcliffe, Islamic Marriage and Divorce Laws of the Arab World (Cambridge: Kluwer Law International, 1996); Donald Eugene Smith, Religion and Political Modernization (New Haven: Yale University Press 1974). 
-Chapter Two-

Legal Practice and Change in Egypt prior to 1897

This chapter consists of two parts. The first section is devoted to showing how the legal system operated in seventeenth- and eighteenth-century Egypt. It touches on important aspects of legal practice in Egypt before the turn of the nineteenth century. This first section addresses the competence and scope of legal authority of both Muslim judges and the Muslim political establishment before the turn of the nineteenth century. Highlighting aspects of the shari justice during seventeenth and eighteenth centuries helps us to recognize the type of changes introduced into this system during the course of the nineteenth century and beyond.

The second section of chapter two sheds light on patterns of legal change accompanied by, or more accurately that arose from, the creation of the modern state in Egypt. It shows how modern legal reform was explained and justified in Egypt.

Administrative Jurisdiction in Seventeenth and Eighteenth Centuries Egypt

In the seventeenth century, Egypt was divided into several units for judicial and administrative purposes. Like miser (Cairo), each Egyptian province consisted of one or more qadas (judicial districts). Each main qada was broken down into nahiyyahi (plural of nahiayyah - sub-district). The qada was presided over by a qadi (Muslim judge). The qadi of the qada had a naib (judge substitute) of himself in every nahiayyah of his qada. ${ }^{1}$ 
The High shari Court of miser, located in Cairo, was the highest legal institution in Egypt, presided over by the qadi of miser. As the qadi of Cairo, he was the head of the entire shari justice system in Egypt. Like other shari courts in eighteenth-century Egypt, the High shari Court of miser was a court of general jurisdiction, the competence of which was not confined to a specific administrative boundary or locality. While functioning like a supreme court, mostly hearing serious cases, the High shari Court of miser did not review decisions made by lower shari courts simply because the concept of appeal was still alien to the shari legal system. ${ }^{2}$

\section{Shari Court Tribunal and Structure}

The Hanafi Madhab (school of jurisprudence founded by the jurist Abu Hanifa 699-767) was the official Madhab of the Ottoman state, and in Egypt as well. Therefore, the qadi of miser was Hanafi (an adherent of the Hanafi madhab). He was the senior judge in Egypt. ${ }^{3}$ Until 1876, the qadi of miser was appointed by the Ottoman Sultan. In theory, the Sultan was the sole source of legal power. As a Muslim ruler, ensuring justice among his subjects was one of his basic responsibilities. The qadi of miser as an appointee of the Sultan, functioned as his deputy, receiving legal power from him and adjudicating on his behalf. However, the qadi was bound by Islamic law and his own conscience in regard to that law. The qadi of miser, was to name and extend the Sultan's legal authority to other qadis of Egypt. Each provincial qadi was to appoint a naib of 
himself in each nahiayyah of his qada. While qadis were able to adjudicate in all legal cases brought before them, naibs were only authorized to adjudicate less serious cases, unless specifically given permission of the qadi. The naibs were appointed for life, the exception being the qadi of miser and his appointed naibs, who were appointed for a term of only one year. ${ }^{4}$

With the exception of the High shari Court of miser, which was located in a designated building in Cairo, the shari courts in the seventeenth and eighteenth centuries Egypt did not have fixed locations. Trials were held either at the qadi's house or in the mosque. ${ }^{5}$ Cases brought to the shari court were tried by one person alone, and that was the qadi. ${ }^{6}$ That is to say, the shari court was presided over by a solitary qadi who passed judgments on his sole authority. There were neither judicial tribunals nor assembly of judges and juries in the Islamic legal system. ${ }^{7}$

Shari Proof System, Trail, and Legal Procedures

Broadly speaking, trials of the shari courts during the period in question were rather simple and mechanical. Aside from oral confession of guilt, oral testimony of shuhud (plural of shahud, eyewitness) were the most important, if not the sole, method of establishing facts recognized by the qadi. Depending on the nature of the case, the plaintiff had to provide at least two shuhud to testify to the validity of the claim. If the required number of shuhud was not met, the case would be dismissed. In the latter 
situation, however, the plaintiff could still request that the attendant take a yamin (oath) of their innocence. Failure to take the yamin would result automatically in conviction. ${ }^{8}$ Written testimony was often presented in legal disputes. However, written testimony did not amount to evidence. When documents, including those issued by the court itself, were presented, the qadi would always demand that the shuhud testify to the validity of the content. In other words, written evidence and/or official documents were not considered to be enough to establish facts unless the content therein was confirmed by at least two eyewitnesses. ${ }^{9}$

Since the shari system of proof depended on eyewitnesses to verify facts, the credibility and integrity of eyewitnesses had to be verified before accepting their testimony. The process of investigating and confirming the accountability and credibility of the eyewitnesses was conducted by persons called $u d u l$ (individuals with a trustworthy reputation). Udul were frequently hired by the qadi for this purpose. In fact, udul served as constant, accountable eyewitnesses of the shari court. The qadi usually dispatched them to the crime scene to identify the suspect and/or gather information about the case. The report of the udul was so crucial that the qadi's decision was shaped by it. Claims were usually heard by the udul first. If the case appeared to be minor, or if reconciliation was possible, the udul would deal with it without the knowledge of the qadi. If the case was serious, the udul would hear the claim, prepare a report, and submit it to the qadi. ${ }^{10}$

Until the early nineteenth century, the functions and roles of the qadi were not strictly defined and were fluid at best. In theory, for the qadi to take action, a case must 
be filed by someone. That is to say, if there was no actual plaintiff, there would be no trial. ${ }^{11}$ Furthermore, there was no clearly defined way of arresting suspects or forcing them to appear before court. The same was true in regards to carrying out the qadi's judgment. Arrests were often made by the police or members of the military. However, the person who brought the charges was usually also the one who arrested the accused. If the crime took place in a certain neighborhood or village, residents of the area were responsible for arresting the criminal or paying blood money to the victim. If theft happened in public places, the attendants of the incident, or those in charge of guarding the area, were deemed responsible for establishing terms for a solution or providing compensation. In most cases, especially criminal ones, if the defendant escaped or refused to show up before court, there would be no trial until both parties, the defendant and plaintiff, were present before the qadi. ${ }^{12}$

In sum, shari court procedures and operations in seventeenth- and eighteenthcentury Egypt were largely determined by the qadi, with intervention of state officials in the legal affairs of the qadi being rare, mostly confined to upholding court decisions or arresting suspects.

Qadi Legal Authority Versus State Authority

Before the creation of a modern state in Egypt in the course of the nineteenth century, the role and functions of the qadi were not strictly defined. According to Farahat, the function of the qadi during the seventeenth and eighteenth centuries was extended to 
include, as he puts it, "strange duties" unrelated to his legal function. For example, the qadi toured the market on occasions to inspect the prices. Those convicted of overpricing were subject to immediate punishment, carried out by the qadi himself. In the countryside, qadis were charged with supervising agriculture and distributing seeds among the peasants. In the situation where the land became barren, the qadi was to submit a report to the government determining whether the administrative officials of the province were responsible. If so, administrative officials would be subject to punishment. $^{13}$

While Farahat emphasizes aspects of the qadis' involvement in areas unrelated to his actual job, Uriel Heyd stresses a much different view, namely, the encroachment of secular state officials on the legal domain of the qadi. Heyd contends that the legal power of the executive officials tended to overstep that of the qadi. According to Heyd, the rule of the qanun (state law) that a criminal must not be punished without being convicted by a qadi, was largely disregarded. Herd essentially blamed the Ottomans for failing to establish a clear-cut distinction between the legal power of executive officials and that of the qadi. ${ }^{14}$ Farahat, on the other hand, suggests that it was impossible to draw such a distinct boundary simply because the concept of separation between powers was alien to the Ottoman lands, and by implication, to Egypt, prior to the turn of the nineteenth century. ${ }^{15}$

In any event, the legal authority of state officials was largely confined to crimes and offenses related to public order and security. The legal authority of government 
officials developed out of two main factors: 1) the limitations of the shari legal system, and 2) the legal right the sharia gives to Muslim political authority to punish acts and behaviors endangering public order, safety, and security.

\section{Limitations of the Sharia and Expansion of the Siyasa Concept}

According to figh (Islamic jurisprudence), there are three distinct legal categories. The first one concerns hudud (punishments for crimes determined by God). It deals with crimes and their punishments as explicitly stated in the Quran. The second category covers matters of qisas (retribution), jinayat (offenses against others), and haqooq al alkrin (other persons' rights). The third legal category is called tazir, or siyasa. Siyasa refers to the unrestricted power given to Muslim political authority to punish harmful behaviors and acts endangering the security of the state and/or public order without the involvement of the qadi. ${ }^{16}$ Prior to the turn of the nineteenth century, crimes and offenses falling under the first and second categories were tried exclusively by the qadi. However, the qadi's competence in cases involving violation of God's and individuals' rights was effectively restrained by the fact that the qadi could not act unless a case was filed by an actual person. The state could not push for charges if the victim did not have heirs. Even though the qadi could act when God's rights were violated, the Hanafi madhab holds that the qadi could not act on his own in any way. Thus, for the qadi to be engaged, cases needed to be brought by another party. ${ }^{17}$

On the basis of siyasa, state officials reserved the right to adjudicate cases related 
to public order and security. The qadi's role in this area was supportive, confined to investigating the case. Having investigated the case assigned to him and establishing the facts, the qadi would submit a report of the results of his investigation to state officials, who would both determine and carry out the punishment. ${ }^{18}$

Because shari rules were strictly defined, interpreted, and applied, and because the sharia does not touch on a number of crimes and offenses, Muslim rulers wishing to maintain law and order in the modern sense may find the shari rules to be lacking. ${ }^{19}$ In theft crimes, shari punishment was applicable only if the stolen goods had a certain minimum value and were stolen from a locked or watched place. ${ }^{20}$ In theft cases examined by Farahat, even though conviction of crime was obvious, the qadi was reluctant to apply shari punishment simply because the shari rules were not met. In such situations, the best the qadi could do was to ask the thief to return the stolen goods. ${ }^{21}$ Implementation of the shari punishment could also be undermined by the concept of shubha (doubt), which infers that any degree of doubt will thwart application of the shari punishment. Thus, in hudud crimes, recanting one's testimony or confession, which remains possible until the last moment before the punishment is carried out, will render the verdict invalid. ${ }^{22}$ According to Abu Hanifa, for the crime of drinking alcohol to be established, the smell of alcohol must still have been present when the incident was reported and the suspect was arrested. If the crime was reported after the smell disappeared, the testimony of the eyewitness would be dismissed. For the crime of murder to be confirmed, at least two eyewitnesses must testify to the crime. For the crime 
of fornication, four male Muslim witnesses must testify to the crime after the suspect admitted guilt. The mature and responsible suspect must confess guilt four times to each count of fornication and four witnesses must testify to the incident and narrate it in detail. If the required number of eyewitnesses was not met, the case would be dismissed. Last, but not least, the death penalty could be applicable only if the victim was explicitly killed by a weapon, a sharp tool, or fire. Other means of murder, such as poisoning or strangulation could not be counted as intentional murder and therefore did not result in capital punishment. $^{23}$

As recent research on legal development in nineteenth-century Egypt has shown, the underlying motivation behind the introduction of the secular legal bodies in Egypt during the nineteenth century operating side-by-side with the shari courts, was not to replace these courts, and by default, the sharia. Rather, the purpose was to supplement the shari courts and to find a solution for legal issues which arose from the strict application and interpretation of shari rules.

As experts of legal history of modern Egypt have observed, the development of the legal system in Egypt in the course of the nineteenth century was closely associated with the establishment of the modern state. According to Peters, the introduction of new laws and legal procedures and the creation of secular legal entities in Egypt were the product of Muhammad Ali's desire to bestow greater legitimacy upon his rule and heighten his power. Muhammad Ali sought to establish a centralized and rational rule in Egypt. The new laws were critical to the policy of discipline and achieving centralization 
and rationalization in his realm. ${ }^{24}$

Khaled Fahmy draws an inseparable link between the founding of the modern state in Egypt and the successful adoption of Western legal categories. As he suggests, the new legal concepts were essentially devised to more effectively monitor crimes than before, and to produce a society that was productive and efficient. ${ }^{25}$ Therefore, in the course of the nineteenth century, for practical reasons and out of necessity, the Egyptian political authority started extending and employing the siyasa concept in order to overcome legal matters resulting from the strict application of the shari rules. Since siyasa was less developed compared to the other two legal categories, the Egyptian government enjoyed a great deal of freedom to expand and elaborate on this legal area. Among many other things, siyasa allowed the Egyptian political establishment to circumvent the strict shari rules and introduce new legal procedures and laws aimed at identifying and punishing more crimes and offences, even when the available evidence was not sufficient from the shari perspective. ${ }^{26}$ Embracing autopsy is a case in point. In the course of the nineteenth century, autopsy reports became one of the most important and effective methods of establishing facts in Egypt. The adoption of forensic medicine, which was not derived from the sharia, did not provoke reaction from the ulama, even thought it was introduced without consulting them or exerting any effort to justify this method in Islamic terms. ${ }^{27}$

On the basis of siyasa, the Egyptian political establishment, without entirely dismissing the legal function and role of the qadi, was able to adopt, justify, and enforce 
Western-inspired legal concepts within the legal practice in Egypt. At first, legal bodies modeled on the West were created, while earlier legal practices continued to operate and remained largely intact. Eventually, as shown in chapter three, waves of legal change hit the shari justice system itself, with the Egyptian government making profound changes to this system, shaping and reshaping it in accordance with modern standards.

\section{A New Legal System in Place}

In the course of the nineteenth century, the punitive and legal authority of administrative officials was gradually transferred to specialized secular legal bodies that were adopting new legal procedures and applying laws issued by the state. At the same time, the qadis stopped serving as examining judges with respect to siyasa cases. Thus, a dual legal system, partly religious and partly secular, came into existence, each part with its own distinct rules. ${ }^{28}$ In order to stress their function as part of the government, the legal bodies created in Egypt during the first half of the nineteenth century and entrusted to carry out laws enacted by the state, were named majalis (councils) instead of mahakim (courts). The majalis were mainly administrative bodies. Trying crimes and offenses was only one aspect of their role and function. Their judgments were to be reviewed and endorsed by the Khedive (Viceroy of the Ottoman Sultan, ruler of Egypt), who reserved the right to change or overturn these decisions at will. ${ }^{29}$

In 1842, a special legal council called al-Jamuyya al-Haqqaniyya was created in 
Cairo. In addition to trying serious crimes, the council functioned as a court of appeal, reviewing the decisions of lower legal bodies, namely, the majalis. In 1849, al-Jamuyya al-Haqqaniyya was replaced by a council named Majilis al-Ahkam, which performed the same functions and remained in operation—except for two short interval periods—until 1889. In 1853, majalis were created in the provinces. They, too, dealt with serious crimes. Their decisions were to be reviewed by Majilis al-Ahkam. In 1871, majalis were established in the small towns, thus completing the majalis legal system. While the majalis functioned as lower courts, Majalis al Ahkam served as a supreme court, whose job it was to ensure that the lower councils were properly carrying out the laws enacted by the state. However, this newly created hierarchical system remained subordinate to the Khedive. ${ }^{30}$

The majalis functioned as complementary legal bodies to the shari courts. Most crimes and offenses, except familial disputes, which remained exclusively within the legal domain of the shari qadi, were now tried by both systems. The qadi was to first review those cases for which he was competent from the shari point of view. He would apply the shari requirements and system of proof. The majalis was to review the cases thereafter in accordance with the penal code enacted by the state, which allowed much more freedom in terms of considering evidence. ${ }^{31}$

Whether the qadi deemed the suspect guilty or innocent, the majalis was to nevertheless try the accused. For example, sulh (reconciliation) was frequently suggested and encouraged by the qadi. Based on sulh, the plaintiff would give up their demand for 
retribution and agree to a financial settlement. Such a settlement, however, did not affect the majalis' ability to try the case according to state law. In cases where relatives of the victim were unknown, a situation that would undermine the competence of the qadi, state officials would try to find these relatives. If no relative of the victim was found, the government would act as a representative of the victim. ${ }^{32}$

With the establishment of the Mixed Courts in 1875, followed by the creation of the National Courts in 1883 and the introduction of French Code in the same year, the dichotomy in the Egyptian legal system became more clear-cut. State-founded secular courts were applying a codified law in which Western influence significantly predominated, and with personnel trained in the modern way. Meanwhile, the qadis of the shari courts were trying according to the sharia, and the law was to be derived from the multifarious classical texts by qadis and lawyers trained in the traditional fashion. ${ }^{33}$

This duality of the legal system lasted until the judicial reforms of 1883 , which put an end to the qadis ability to adjudicate criminal cases. From that date forward, the qadi's function was effectively restricted to matters of personal status and awqaf (endowments). As pointed out earlier, the creation of a new legal system did not put an end to the previously established legal practice. The shari courts continued to operate side-by-side with the new legal entities. With the exception of a few important changes, such as abolishing the $u d u l$ system in 1867 and putting an end to the qadi's practice of corporal punishment in 1861 , the shari legal system remained largely intact. ${ }^{34}$ In the course of the second half of the nineteenth century, however, the Egyptian government 
began sweeping its power over the shari courts, embarking on a program of shaping and reshaping the shari court system in accordance with modern parameters, thus contributing greatly to the transformation of this system in modern times. 
Notes to Chapter Two

1. Galal H El-Nahal, The Judicial Administration of Ottoman Egypt in the Seventeenth Century (Minneapolis: Bibliotheca Islamica, 1979), 12-17.

2. Muhammad Nur Farahat, al-tarikh al-ijtimai lil-qanun fi misr al-hadithah (Cairo: Markaz ibn khaldun lil-dirasat al- inmaiyah, 1986), 368-379. Sami Zubaida points out that even though shari judgments were not subject to appeal within the shari legal system, sufficiently influential and well-connected figures could challenge these judgments by taking theme to the Muslim tribunals of the ruler, or other administrative entities, Sami Zubaida, Law and Power in the Islamic World (New York: I.B. Tauris, 2003), 44.

* The High shari Court of miser was initially called al-Bab al-Ali Court, while the qadi of miser was called qadi asker. For the sake of convenience and consistency, the present chapter employs the nineteenth century term, that is, The High shari Court of miser.

3. Nahal, Judicial Administration, 13-14.

4. Farahat, al-tarikh al-ijtimai, 54-57, Nahal, Judicial Administration, 14-16.

5. Nahal, Judicial Administration, 12-13, Zubaida, Law and Power, 46.

6. Farahat, al-tarikh al-ijtimai, 58, Zubaida, Law and Power, 44.

7. Zubaida, Law and Power, 45.

8. Nahal, Judicial Administration, 28, 18, 19; Matthew Ross Lippman, Seán 
McConville, and Mordechai Yerushalmi, Islamic Criminal Law and Procedure: An Introduction (New York: Praeger,1988), 71.

9. Nahal, Judicial Administration, 18-19, Farahat, al-tarikh al-ijtimai, 408-9.

10. Nahal, Judicial Administration, 18, 19 Farahat, al-tarikh al-ijtimai, 409-10.

11. Farahat, al-tarikh al-ijtimai, 352, 473, 475.

12. Nahal, Judicial Administration, 20-21, 28.

13. Farahat, al-tarikh al-ijtimai, 354-5, 385.

14. Uriel Heyd and V.L. Menage, Studies in Old Ottoman Criminal Law (Oxford: Clarendon Press, 1973), 219-21.

15. Farahat, al-tarikh al-ijtimai, .349-56.

16. Peters, "Islamic and Secular Criminal Law," 71, "The Codification of Criminal Law," 211-12.

17. Nahal, Judicial Administration, 25-26.

18. Farahat, al-tarikh al-ijtimai, 478.

19. Peters, "The Codification of Criminal Law," 212.

20 Ibid, 212.

21. Farahat, al-tarikh al-ijtimai, 487-89

22. Peters, "The Codification of Criminal Law," 212. 
23. Farahat, al-tarikh al-ijtimai, 486, Peters, "The Codification of Criminal," 212.

24. Peters, "For His Correction," 172-73.

25. Fahmy, "The Anatomy of Justice." 226.

26. Peters, "Islamic and Secular Criminal," 71-72, and "The Codification of Criminal Law," 212-13.

27. Fahmy, "The Anatomy of Justice."

28. Peters, "Islamic and Secular Criminal Law," 72.

29. Ibid, 75.

30. Ibid, 75-76.

31. Ibid, 76, 79, and "For His Correction," 167, Fahmy, "The Anatomy of Justice," 261.

32. Peters, "Islamic and Secular Criminal Law," 88-9, "The Codification of Criminal Law," 221.

33. N.D Anderson, "Law Reform in Egypt 1850-1950," in Political and Social Change in Modern Egypt: Historical Studies from the Ottoman Conquest to the United Arab Republic, ed Holt P.M, (London: Oxford University Press, 1968) 221.

34. Peters, "Islamic and Secular Criminal Law," 88. 


\section{-Chapter Three-}

Transformation of the Shari Justice System 1855-1930

Properly situated, modern legal change in Egypt has been discussed in the context of the establishment of the modern state in this country. An emphasis has been placed on the tendency and particular intent of such a state to bring all activities under its control and supervision before regulating them. While symbolically part of the Ottoman Empire, Egypt developed its own distinctive legal system, passing laws and legal procedures that suited its particular needs. By doing so, Egypt acted as an autonomous, independent state. It is true that the Ottoman government granted rulers of Egypt certain legal privileges that enabled them to independently manage legal affairs of Egypt. However, in altering and transforming Egypt's justice system, Egyptian rulers claimed to be acting not based on these privileges, but by virtue of their sole role as the source of legal and political power in Egypt. In other words, they proclaimed themselves as absolute, legitimate, independent Muslim rulers of Egypt.

Traditionally, one of the most important rights of the sovereign was the appointment of the qadis. The qadi served as a representative of the sovereign. The qadi was to judge legal cases on behalf of the ruler, deriving his legal authority from him. The competence and scope of the qadi's legal authority was to be specified in, and determined by, the appointment. To consolidate their claim both locally and outside as the sole of legal authority and as independent Muslim rulers, rulers of Egypt extended their authority over the shari justice system. Appointment of all shari qadis, including the head of the 
shari justice system and the Grand Mufti of Egypt, were made the exclusive right of Egypt's ruler. This move was of immense importance and was validated by the Egyptian ulama. In addition, the Egyptian ulama helped to develop a highly complex jurisprudential argument backing this claim. It is important to note that the Egyptian ulama, when confronting the regime could, and indeed did, cast doubt on Egyptian rulers' claim as legitimate absolute Muslim sovereigns. They switched their loyalty and backed the Ottoman claim (see chapter four).

Focusing on the period from 1855 through 1930, this chapter illustrates how the shari courts were transformed and integrated into the state system. The transformation of the shari courts was mainly the outcome of the need and desire to stress Egypt's autonomy from the Ottoman Empire and its distinct legal and political identity. For the ruler of Egypt, extending his authority over the shari justice system was a move that would no doubt consolidate his legitimacy as an absolute Muslim ruler both internally and externally. Other important elements that contributed to the transformation of the shari courts highlighted in chapter three were print media and the efforts of some distinguished Egyptian thinkers and reformers.

Broadly, the incorporation of the shari courts into state structure and the transformation of these courts were accomplished through a series of steps. First, the Egyptian government obtained the right from the Ottoman Sultan to appoint all qadis of the shari courts, including the head of the shari legal system, the qadi of miser. Shortly thereafter, all shari qadis were made mere state employees. The government then began 
extending its authority and supervision over all activities of the shari courts. The shari courts were administratively and hierarchically reorganized. The state introduced profound changes to their functions and operating procedures. With the creation of a modern school aimed at providing shari qadis with modern training and knowledge, much of the transformation of the shari legal system was achieved.

\section{Integrating Shari Tribunal into State System}

Conventionally, appointment of the qadi of miser was the exclusive right of the Ottoman Sultan, Egypt's supreme ruler. The appointment was typically made by an Ottoman faraman (decree) issued by the Sultan for a one-year term only. The qadi of miser, in turn, was to name other qadis of Egypt. The qadi of miser did not receive a regular salary from either the Ottoman or the Egyptian government for his legal services. As an alim, delivering justice on behalf of Muslim ruler was one of his religious obligations. Like other qadis, the income of the qadi of miser was derived from his share of collected court fees, the major portion of which was to be transmitted to the Ottoman government. ${ }^{1}$ In the course of the second half of the nineteenth century, this situation began to change dramatically.

In 1855 , the Khedive obtained the right to appoint all shari qadis in Egypt, except the qadi of miser. ${ }^{2}$ Subsequently, the government designated fixed salaries for the legal services of the shari qadis. ${ }^{3}$ The Egyptian government then ordered that all fees collected by the shari courts be transmitted to the Egyptian government. ${ }^{4}$ In the same year, shari 
court fees were formally regulated, and shari courts all over the country were instructed to apply them. ${ }^{5}$

In the early 1870s, the Egyptian government concluded an agreement with the Ottoman Empire to the effect that the former was to pay 250 Ottoman pounds every month to the individual appointed by the Sultan as the qadi of miser in exchange for keeping this person in Istanbul. A naib (judge substitute) of the qadi of miser was to be selected by the Khedive and formally appointed by Ottoman faraman. However, the Khedive, apparently ignoring the latter part of the agreement, named an alim, Abdulrahman Nafez Effendi, not as the naib, but as the actual qadi of miser for five years, while keeping for himself the right to renew the appointment for an additional five years. And it was the Egyptian ulama who supported and justified this move by the Khedive. An Egyptian ulama committee was formed to elect and recommend the wouldbe qadi of miser. The committee convened and chose Nafez. Shortly thereafter, the Khedive issued a high decree appointing Nafez as the new qadi of miser. Backed by the Egyptian ulama, the Khedive was certainty emboldened. He was confident enough to ignore the Ottoman Sultan by single-handedly appointing the qadi of miser.

Nafez remained in office for more than fifteen years. From the date on which the Khedive appointed Nafez, the Ottoman government stopped issuing the yearly faraman of appointment to this office. ${ }^{6}$ Facing the same fate of other qadis in Egypt, the qadi of miser started receiving a fixed salary for his legal services from the Egyptian government. In addition, he was henceforth called an employee of the Egyptian 
government. $^{7}$

It should be mentioned that even though the faraman of investiture sent to the new Khedive in 1879 did explicitly acknowledge the Khedive's authority over civil, financial, and judiciary administration in Egypt, the Khedive's right to appoint the qadi of miser remained only implicitly granted. ${ }^{8}$ The Khedive, however, made it clear, officially, that he reserved the right to appoint the qadi of miser, the Grand Mufti, and all shari qadis in Egypt. Article 10 of Layihat tartib al-Mahākim al-Shariyah wa-al-ijraat al-mutaalliqah bihā, or The Ordinance of Organizing Procedures of the Shari Courts of 1897 (henceforth, LTMS of 1897) provides that, "Electing the qadi of miser is our [the Khedive's] vested right. He [the qadi] will be appointed in accordance with the applicable rules. Electing and appointing the mufti of Egypt is our prerogative. He [the Grand Mufti] will be appointed by our command according to the common procedures." Article 11 of the same ordinance states that, "Appointing all other qadis, members and muftis of the shari courts will be made by a decree from us [the Khedive] upon the recommendation of nazer al-haqqanya [minister of justice]."9

Transformation of the Shari Justice System

By 1897, the Egyptian government had already secured the right to appoint all qadis of Egypt, including the qadi of miser, and made them state employees. Subsequently, additional measures were taken that significantly increased involvement of 
the Egyptian government in the administration of the shari courts. These steps included regulating the internal rules and operating procedures of the shari courts, collecting and preserving data and information concerning operation of shari courts in official records, conducting regular inspection of the works of the shari, and creating a disciplinary council for the shari court tribunal.

\section{Regulating and Recording Shari Court Operation}

In 1897, the Egyptian government issued a regulation that introduced a new set of rules and procedures governing operation of the shari courts. The new regulation essentially laid down rules for administrating cases handled through the shari court system. It included detailed instructions on how the shari courts and majalis associated with them would conduct case hearings, establish facts, deliberate and pass judgments, and manage the appeal process. It also touched work policies such as absence, business days and hours, vacations, promotion criteria, and so on. The new regulation also established how data and information concerning operation of the shari courts was to be preserved in official records. The new regulation contained a detailed description concerning official recording methods and formats that were to be followed by shari courts all over the country. ${ }^{10}$

In short, the Egyptian government established rules and procedures governing the function of the shari courts and created official records to preserve data and information regarding the operation of these courts. In order to enforce the newly-introduced rules 
and regulations and to ensure compliance with them, the Egyptian government started carrying out regular inspections of the works of the shari courts.

Inspecting Shari Courts

According to a high decree issued in May of 1898, all files and records of the shari courts were to be subject to inspections carried out by employees hired by nazarat al-haqqaniya [ministry of justice] for this purpose. With the exception of the High shari Court of miser, all legal and administrative operations of the shari courts were to be regularly inspected by nazarat al-haqqaniya. Inspection of the High shari Court of miser was to take place at specific times upon request from its presiding qadi.

Justice ministry inspectors were to either visit the shari courts to investigate their operation, or simply review their records at nazarat al-haqqaniya. In the latter situation, inspectors reserved the right to ask the shari courts for copies of final judgments and any other documents the inspectors deemed necessary for the inspection. After each inspection, inspectors were to submit to nazarat al-haqqaniya a report including their notes and evaluation. Inspectors were to abide by the instruction of nazarat al-haqqaniya. At the beginning of every month. each shari court was to provide the deputy of nazarat al-haqqaniya with a list of cases that had already been heard, along with their final judgments, as well as cases that were still under consideration. This list was to be prepared according to certain formats determined by nazarat al haqqaniya. The general 
deputy inspector at nazarat al-haqqaniya was to provide a detailed report concerning the overall operation of the shari courts by the end of each year. ${ }^{11}$

In summary, the Egyptian government began closely monitoring activities of the shari courts in order to ensure compliance with the newly-introduced rules and regulations. To make sure that employees of the shari courts were meeting performance standards, behaving appropriately in the workplace, and complying by the rules established by the state, the Egyptian government created a disciplinary council whose job was to take disciplinary actions to improve unacceptable behavior and performance, and to punish those who violated the rules.

\section{Shari Disciplinary Tribunal}

In September of 1897, nazarat al-haqqaniya issued a decree specifying how the discipline of the shari tribunal was to be enforced. The decree also outlined types of disciplinary actions to be taken against those who did not abide by the rules. With the exception of the qadi of miser and the Grand Mufti, all members of shari courts were to be subject to disciplinary actions taken by a disciplinary council. Types of disciplinary measures mentioned in the decree included suspending payment of the monthly salary, work suspension, demotion, job transfer, dismissal with partial or total suspension of the monthly salary and rewards.

Nazer al-haqqaniya (the justice minister) was authorized to single-handedly 
enforce the first and second types of punishment and to order job suspension until the disciplinary case was heard and a decision made. The decree in question emphasized repeatedly that it was permissible to dismiss any employee of the shari courts if they were derelict in the performance of their job duties or committed any act undermining the dignity of justice. In closing, the decree made it clear that the Egyptian government reserved the right to act alone and dismiss any qadi or other employee from their job without consultation with the disciplinary council. ${ }^{12}$

That the Egyptian government could now dismiss a qadi at will constituted an unprecedented development. The qadis were accustomed to being appointed for a lifetime. Previously, dismissal of qadis could only be done by a decree from the ruler himself. When the Khedive issued a decree in April of 1874 authorizing nazar qldakhiliyah (interior minister) to temporarily suspend provincial and major cities' qadis against whom complaints were filed, the ulama were outraged. The ulama strongly condemned the move, assuming that nazar ql-dakhiliyah had been endowed with authority to dismiss the qadis. In response, the Khedive issued another decree in December of the same year in which he assured the ulama that as a rule, qadis would be appointed for life, that only the Khedive had the right to dismiss qadis and only under certain circumstances, and that suspended qadis would be replaced by temporary ones chosen in consultation with the ulama. ${ }^{13}$

In sum, by the end the nineteenth century, the shari courts were completely and effectively integrated into a state system. As will be illustrated below, operations and 
functions of the shari courts, such as court case management system, were set up and regulated in a way that rendered these traditional institutions relative, if not totally compatible, to modern conditions and standards.

Defining Administrative Jurisdiction and Competence of the Shari Courts

Up until 1880, shari courts still had general jurisdiction over most legal matters. ${ }^{14}$ By 1897, however, shari courts had both a clear-cut hierarchical structure and strictly defined administrative and jurisdiction boundaries. Furthermore, by the same year, competence of the shari courts was effectively and officially confined to matters of personal status and awqaf.

According to LTMS of 1897, the shari courts were divided into four categories: marakeaz (country subdivision) courts, mudiriya (directorate) courts, muhafazah (province) courts, and a high court, that is, the High shari Court of miser in the Egyptian capital. Each court type had jurisdiction only over its administrative boundary lines. ${ }^{15}$ While the High shari Court of miser served as a supreme court, marakez courts functioned as courts of first instance, only hearing cases concerning marriage, dowry, wedding expenses, child custody, divorce, and other issues related to marriage. Serious familial and waqf cases transcending the scope of the legal authority of the marakez court were to be forwarded to the shari council of the administrative division within which the marakez court was located. Appeals against the decisions of marakez courts were to be 
reviewed solely by the shari councils. ${ }^{16}$

\section{Admitting New Types of Evidence}

By 1897 , oral testimony was no longer the only accepted method of establishing facts admitted by the shari court. This represented a departure from the traditions of the shari court system. While emphasizing the longstanding method of proving facts, namely, oral testimony, article 25 of the LTMS of 1897 added that "Written affirmation is [as valid as] oral testimony. ${ }^{17}$ Recognition of written testimony as valid was an important development paving the way for admitting more types of evidence. By 1910, the Egyptian government instructed the shari courts to consider both official and unofficial documents as sufficient evidence. Article 138 of the LTMS of 1910 provided that, "Official and customary documents are sufficient to [solely] make a judgment based on them, and they do not require any additional proof [that is, oral testimony, to support them]."18

Development of Shari Justice Decision-Making Process

Another important facet of the transformation of the shari court system was that by 1897 cases brought to the shari courts were no longer heard by one person alone, that is, the qadi. The same was also true for the shari court decision-making process.

Article 6 of the LTMS of 1897 states that:

The [High] shari Court of miser is to consist of the qadi of miser and five other members. [Court] decisions are to be made by three of them, one of whom is the qadi, acting as their chairman, or whoever he [the qadi] 
chooses to act on his behalf....Each provincial court is made up of a qadi and two members, one of whom is the mufti of the area. [Court] decisions are to be reached by the three [members], with the presiding qadi acting as their chairman. ${ }^{19}$

Appeal in the Shari Justice System

As mentioned in chapter two, the concept of appeal was rather alien to the shari judicial practice. Towards the end of the nineteenth century, however, decisions of the shari courts could be appealed. According to the LTMS of 1897, appeals against judgments of the lower shari court were to be submitted to the shari council of the administrative division or province within which the lower court that made the contested judgment was located. Appeals against the judgments of shari councils, conversely, were to be forwarded to the High shari Court of Appeal of miser for review. Judgments of the shari councils and the High shari Court of Appeal of miser were to be made by unanimity among the members or by the majority. ${ }^{20}$ 


\section{Execution of Judgments}

There was no established way in the shari legal system to enforce decisions made by the qadi. While government officials sometimes stepped in to execute the qadi's judgments, this was infrequent and rather unsystematic. Towards the turn of the twentieth century, the Egyptian government officially committed itself to carrying out judgments of the shari courts, specifying and employing various and effective ways to do so.

According to Article 92 of the LTMS of 1897, final decisions of shari courts that were not appealable would be implemented by the administration of the division within which the court that made the decision was located. No fees were to be collected from the plaintiff. Government representatives were authorized to resort to any means, including force, to implement shari judgments. Article 93 of the LTMS of 1897 provided that shari decisions concerning personal matters would be carried out by force if needed, even if this was to lead to entering the houses of the defendants in order to implement them. In addition, the LTMS of 1897 established that if the losing party failed to pay their financial obligations as determined by the shari court, government officials could collect the amount of money needed from the income of the losing party. According to article 94 of the LTMS of 1897, if the defendant failed to fulfill their financial responsibility as determined by the court in a personal lawsuit, it was permissible to deduct the amount of money needed from their income, be it monthly salary, daily payment, or crop. ${ }^{21}$ 
Codification of the Law and Establishment of a Modern Law School

The call for creating a school that would supplement al-Azhar for shari qadis and for restricting interpretation of the sharia did not come from within the Egyptian government. Rather, it came from members of the ulama circle. A distinguished alim, Muhammed Abduh (1849-1905), assumed the task of proposing and justifying these measures. He put forth a persuasive appeal and a well-constructed argument suitable to the situation at hand.

\section{Abduh's Report}

As will be discussed in detail in the following chapter, the ulama succeeded in thwarting a major attempt made by the government to allow qadis from the National Court of Appeal to join the tribunal of the High shari Court of Appeal. That is to say, the ulama rejected qadis not chosen from their group to serve in the shari courts. In doing so, the ulama were defending and asserting their long-standing position as experts in the sharia.

Abduh was appointed Grand Mufti by the government in 1899, after the government failed to execute the aforementioned plan. After the plan faltered at the hands of the ulama, including the Grand Mufti, sheikh Muhammad al Abasi, Abasi was fired. Abduh was appointed after him as the Grand Mufti. Subsequently, the government formed a committee to deliberate the situation of the shari courts and to come up with 
effective and agreeable ways to reform these courts. Abduh, who was also a member of the reform committee, was commissioned to visit and inspect the shari courts throughout the country and submit a report comprising the results of his inspection and observations:

I learned after I was appointed as the mufti of the Egyptian lands that I was to be a member of the committee entrusted by the government to introduce necessary changes to the shari courts... I [therefore] thought I should be fully aware of this great matter [reforming the shari courts], which requires further research and knowledge of the condition and operation of these courts in order to identify their shortcomings and determine [effective] ways to overcome them. ${ }^{22}$

Abduh spent the summer of 1899 traveling across the country, visiting the shari courts, court by court, examining their records and inspecting their operations. Upon his return, he submitted a report of 83 pages summarizing the results of his inspection. Abduh's report is of historical significance. Produced by a preeminent alim, an expert in the sharia, a qadi, and one of the highest religious and official figures in Egypt at the time, the Grand Mufti, the report provides valuable insights into the condition and operation of the shari courts by the turn of the twentieth century. Furthermore, and perhaps more importantly, Abduh's evaluation of the condition of the shari courts and the reformist steps he recommended to enhance the conditions of these courts played a vital role in paving the way for the subsequent and profound changes introduced to the shari justice system.

At the beginning of his report, Abduh pointed to what he regarded as an undeniable fact: that complaints about performance of the shari courts had increased 
considerably, becoming widespread throughout the country. Apparently addressing serious concerns among the ulama's circle regarding the fate of the shari courts, Abduh strongly rejected the call to abolish these courts. He zealously defended the shari courts, arguing that the shari courts were the protector of Muslim tradition and custom. For him, the shari courts played, and would continue to play, a pivotal role in maintaining the strength and sense of cohesion of the Muslim family and society alike. ${ }^{23}$

Abduh portrayed the condition of the shari courts as increasingly deteriorating, and suggested that this situation constituted a real threat to the very existence of these courts, Abduh stressed a number of factors responsible for the decline of the shari courts. He then recommended taking urgent and crucial measures to considerably enhance the state and function of these courts. Abduh's critique concentrated largely on two major issues: the poor performance of the shari court tribunal, which he attributed to a lack of qualification; and serious problems in the shari court decision-making process.

Evaluating the performance of the shari qadis, Abduh observed that:

I found the shari and administrative knowledge of many shari qadis, especially in the marakez [courts], unpleasant... I saw the shrewd qadi of them trying to resolve almost all disputes through reconciliation so that he could avoid making a judgment [simply because he was not qualified]... I found many legal errors in the decisions [of the shari qadis].... Many [qadis] depend heavily on stenographers, whose situation has been described earlier [as worse] to follow and carry out the regulations. ...Currently appointed qadis are chosen from among al masheikh who were isolated from the real world during their study at the mosque or school. Their legal knowledge is confined to statements they read in fiqh books... ${ }^{24}$

To enhance the performance of the shari qadis, Abudh recommended devising a 
modern study program for them:

Possession of the al alamyah [degree of al-Azhar] should remain [one of the requirements for becoming a qadi] as stipulated in the Ordinance [of the shari courts of 1897]. However, a [comprehensive] fiqh book should be added to the required courses of this [qadi] degree. [The required book] is to provide practical knowledge concerning jurisdiction and muamalat [the part of Fiqh dealing with relations between people]. [Students'] knowledge of fiqh is to be tested based on this. [By the time they complete the required courses,] students must possess writing skills, adequate knowledge of math, shari court system, religious literature, and some [basic] knowledge of history and geography... The [program's] study period is to be four years. No one may be [granted a certificate of qualification for the shari qadi position] unless possession of knowledge [of the abovementioned subjects and areas] has been verified and confirm.... ${ }^{25}$

As for the shari court decision-making process, Abduh pointed out to the

difficulties surrounding the conduct of this process, resulting in common legal errors in the shari judgments:

[Shari qadis are currently] adjudicating in accordance with the opinions of the ulama on the sharia. [These opinions,] as found in the [fiqh] books, are characterized by disagreements [due to differing interpretations of the Sharia]. [Making a sound judgment] requires [extensive] research and [applying] tarjih (preponderance), a difficult process that entails going through monumental compilations... and many qadis are not capable of doing so... [As a result,] the number of [shari] judgments with legal errors has increased. ${ }^{26}$

To overcome problems in the shari court decision-making process, Abduh

proposed and justified consolidating the laws concerning matters of personal status and

awqaf into a unified structure:

An ulama committee is to be entrusted to deduce and put together [certain] shari judgments covering all matters of maamlayat, especially matters of personal status and awqaf... [Judgments] concerning these two areas are to be collected and put together in one book. Qadis will be ordered to adjudicate according to this book... ${ }^{27}$ 
Abduh's report was well received by the Egyptian government and media. Once submitted, the report was immediately published. Egyptian newspapers were following up on Abduh's mission, providing timely coverage of both his travels and his report. The report quickly began to capture public attention and interest. According to the alMoayyed newspaper, 'Egyptians' demand for the report is increasing considerably, becoming the topic of the hour everywhere in the country.",28

For its part, the Egyptian government promptly entrusted a committee to examine the report and consider its reform package. Following Abduh's advice, the Egyptian government ordered that membership of the reform committee be confined to the ulama, a move that was highly praised by al-Moayyed:

This step [limiting membership of the reform committee to the ulama] will prevent the unqualified non-ulama group from interfering in shari matters, which are not their area of expertise. No doubt that this is [a move in the right direction toward] the real reform, keeping [the government's genuine efforts to reform the shari courts] away from rumors and suspicion. ${ }^{29}$

\section{Codifying the Law}

As a sign of sweeping acceptance of the idea of unifying and harmonizing shari law, Majlis Shura al Quaneen itself, along with some influential opponents of the shari courts' reform, strongly backed a reform proposal aimed at confining the application of the sharia in personal status matters to the opinions of the best and most broadly accepted authorities in the Hanafi madhab. ${ }^{30}$ 
In his report of 1906, Egypt's top legal adviser pointed out that upon the request of Majlis Shura al Quaneen, and the approval of the praiseworthy qadi of miser, the government entrusted an ulama committee to examine two compilations. The first compilation concerns personal status law (hanfi), while the second compilation deals with awqaf matters. According to Egypt's top legal adviser, the objective of this committee was to deduce and amalgamate shari judgments regarding these two fields, and to formulate these rulings in accordance with modern formulation of laws. He also reported that while a book of personal status law had been completed, the part dealing with awqaf was not finished yet. ${ }^{31}$

It is uncertain whether the Egyptian government instructed the shari qadis to rule according to these two books. However, by 1910, the shari qadis were officially ordered to apply only the most authoritative and widely accepted Hanfi opinions. Article 280 of the LTMS of 1910 prescribes that, "Judgments must be based on the most preponderant of the opinions of the Hanafi madahb, on what is stated in this regulation, and on madhab of Abu Youssef (Abu Hanifa's disciple) if there is disagreement between the spouses concerning the dowry." 32

Rendering the part of the sharia dealing with matters of personal status to a rather legal code coincided with another development that was equally important: the creation of a school of jurisprudence for the shari tribunal, the purpose of which was to provide this tribunal with modern legal training and knowledge. 
School of Islamic Jurisprudence

It was not only government involvement with legal reform that constrained the Egyptian ulama, but in the late nineteenth century the Egyptian media began promoting the creation of a school to rival al-Azhar. Throughout the second half of the nineteenth century until the beginning of the twentieth century, various Egyptian newspapers had been regularly devoting sections to cover the function of the shari courts. Generally, reports and stories in the Egyptian newspapers tended to portray the shari court tribunal as an unqualified group whose lack of efficiency and outdated legal concepts and conduct resulted in unjust consequences that added to the suffering and hardship of the victims, most of whom were women. ${ }^{33}$

It was Egyptian newspapers, along with Abduh's report, that paved the way for introducing significant changes to the shari justice system. It should be mentioned that there is evidence suggesting that the idea of creating a modern school for shari qadis was also promoted by British colonial influences. A school of law already created in Sarajevo with the objective of providing Muslim judges with modern legal training and education, was deemed an example worthy of following. Evelyn Baring, First Earl of Cromer, British controller-general in Egypt, had reportedly worked closely with Abduh and other members of the committee entrusted to devise a specific plan to create a similar school in Egypt, supplying the committee with the necessary information concerning the structure, 
function, and program of the school of Sarajevo. ${ }^{34}$

Preparation for the establishment of the School of Islamic Jurisprudence was underway and going smoothly until July of 1905, the date on which Abduh died. Here, the school project appeared to have failed as it had lost its strongest and most enthusiastic proponent. However, one of Abduh's pupils, Rashid Rida (1865-1935), the owner of one of the most influential newspapers at the time, al-Manar, began reviving the idea of the shari School of Islamic Jurisprudence. In articles published specifically for this purpose, Rida emphasized the premises of the argument already advanced by advocates of the school: that the current condition of the shari qadis tribunal was miserable, and that in order to improve the performance of the shari qadis, a school promoting modern legal functioning must be created. At the same time, another disciple of Abduh, Saad Zaghloul (1859-1927), embraced the idea of founding the School of Islamic Jurisprudence. As soon as he became nazer nazarat al-maarif [Minister of Education], Zaghloul started putting the school plan into effect. ${ }^{35}$

As a direct result of Zaghloul's relentless efforts and deep commitment to the school project, a high decree was issued on February 25, 1907 ordering that a school for shari qadis, stenographers, and attorneys be founded. Apparently trying to assure the worried ulama that the purpose behind the creation of a new law school was not to displace al-Azhar but to supplement it, the new school was to be an essential part of alAzhar. In addition, candidates for the school programs were to be chosen from among students of al-Azhar. However, slightly distancing it from the old institution, the school 
was to have its own distinctive place within al-Azhar. Furthermore, the school, while placed under the supervision of sheikh al-Azhar, was to be administrated by a principal appointed by nazer al maarif. The Egyptian government's intent to jointly supervise the newly created law school with al-Azhar was most likely to overcome any possible opposition to the new school.

According to the aforementioned decree, the school was to consist of two departments. The first department was devoted to graduating shari stenographers, while the second department was designated for graduating shari qadis, muftis, and attorneys. The study period in the first department was five years. Once the required courses in this department were completed, students had to successfully pass an exam prepared and administered by a committee consisting of sheikh al-Azhar, or someone representing him, acting as the committee's chairman, and two members chosen by nazer al maraif. Graduates of the first department were to receive a certificate of qualification from alAzhar testifying to their ability to serve as professional shari stenographers. If they wished to become qadis or attorneys, graduates of the first department could pursue their education in the second department.

The study period in the second department was four years. Having completed the required classes, students were to pass a final examination prepared and administered by a special committee. The committee was to be made up of shukh al-Azhar, or someone representing him, serving as its head, and five members chosen by nazer al mararif from among the ulama of al-Azhar and individuals with technical occupations from outside al- 
Azhar. Graduates of the second department were to receive a certificate of qualification from al Azhar testifying to their competency to function as professional shari qadis, muftis, and lawyers.

In both departments, the study period for each semester was one year. An exam was to be set up in June of every year to test the students' knowledge in the required courses. No student was to move to the next level in the program until after passing the oral and written examinations. Admission to the school was to be decided by an exam designed and administered by a committee consisting of sheikh al-Azhar, or someone representing him, functioning as the committee's chairman, and two members chosen by nazer al marrif. School instructors were to be chosen from among the Azhari ulama or Muslim noon-ulama, teachers known for their good reputation and expertise in the subjects they were hired to teach.

A committee was to decide school curriculum and internal regulations and rules. This committee was to be made up of sheikh al-Azhar, or someone acting on his behalf, the Grand Mufti, the school principle, and two members chosen jointly by nazer al marrif and nazer al haqqaniya. Determining such matters as the internal regulation of the school, study programs, school instructors, and examination panels were entrusted to a special committee called the administration committee. The administration committee was to be made up of sheikh al-Azhar, acting as its chairman, the Grand Mufti, the school principal, and two members appointed by the nazarat al marrif in consultation with nazer 
al haqqaniya. ${ }^{36}$

On May 14, 1907, nazarat al marrif approved a draft of the internal regulation of the School of Islamic Jurisprudence submitted by the administration committee. ${ }^{37}$ In October of the same year, the School of Islamic Jurisprudence was officially inaugurated. Once the school opened, 1000 students were reported to have submitted their applications to the new school. Out of this large number, only 191 were admitted, 177 to the first department and 14 to the second department. ${ }^{38}$

Despite signs of success and progress, however, the School of Islamic Jurisprudence was rather short-lived, officially closing in 1930. Factors leading to the closure of the school, as well as its far-reaching effects on Egyptian society, are highlighted and discussed below.

Closure of the School of Islamic Jurisprudence

As previously noted, advocates of the School of Islamic Jurisprudence seem to have tried to court the ulama who were suspicious of the school. The school was attached to al-Azhar and placed under the supervision of sheikh al-Azhar. Students of the school were chosen exclusively from among students of al-Azhar. Most of the teachers of the school were Azhari. By and large, the ulama were included in most aspects of the school project and took part in almost all school affairs and activities. Nevertheless, the school faced ruthless opposition from one faction of the ulama. 
As far as this group of the ulama was concerned, the School of Islamic Jurisprudence constituted a real threat to the authority of the al-Azhar since the school would certainly strip al-Azhar of one of its most important functions, which was providing qadis for the shari courts. The fact that the state-founded Dar al Uloom (School of Sciences) had extracted from al-Azhar the job of graduating Arabic teachers was still vivid in their memory: "What was left to the Azharis then were merely positions of mosque affairs such as immama [leading prayers] and katawtaba [preaching during prayers]." 39

Testifying to their concerns about the impact the school might have on al-Azhar opponents of the school proposed that, "students of al-Azhar be considered as qualified [as the graduates of the school] to assume legal positions [in the shari courts.]" Zaghloul, however, dismissed the proposal on the grounds that, “...the government deemed alAzhar unable to provide [qualified] qadis.... if the government accepted such an offer, this will contradict the plan [to supply the shari courts with professional qadis receiving a degree of modern training and education] ..." For Zaghloul, agreeing to the ulama's proposal would make no sense, since:

...the government has succeeded in overcoming the many obstacles [which faced the school project] and [the government] has [finally] achieved its objective: students rushed to it [the school]. The ulama not only ceased to oppose it, but also have come to accept the school and work at it [as teachers] and even sent their sons to study there. In last December, majlis shora al quaneen praised the government for creating it...after all this, the government would accept that al-Alzher compete with this school ... [?] 
Zaghloul conceived the ulama's compromise, to include into the al-Azhar's curriculum all subjects taught at the school of Islamic of Jurisprudence as "an explicit recognition that nothing in these subjects is in contradiction with the sharia." 40

Opposition to the School of Islamic Jurisprudence remained vivid, and apparently was stronger than Zaghloul thought. Once the School of Islamic Jurisprudence provided its first wave of graduates, al-Azhar strongly opposed appointment of these graduates as qadis in the shari courts. As a result, a heated dispute over this matter erupted between Zaghloul and advocates of the school and those who opposed it. Finally, a mediated solution was reached: shari qadis were to be chosen in equal number from both the graduates of the School of Islamic Jurisprudence and those of al-Azhar. Zaghloul welcomed such a settlement, seeing it as a clear recognition of the School of Islamic Jurisprudence from its opponents. ${ }^{41}$

Another serious concern the School of Islamic Jurisprudence generated was that the school was promoting ideas, knowledge, and trends both disapproved of and feared by its opponents. The school accommodated noon-ulama instructors with secular backgrounds and tendencies, who were teaching and advancing noon-Islamic subjects among their students. Testifying to their sensitivity toward unfamiliar topics taught at the School of Islamic Jurisprudence, opponents of the school criticized the chemistry class required in the qadi study program, labeling the class as inappropriate and in outright contradiction to the sharia. In response, the class was renamed "Features God Put in the Objects," while the original content was kept intact. This was reported to have put an end 
to opposition of the class. ${ }^{42}$

When Zaghloul left the office of nazer al marrif, the School of Islamic Jurisprudence became increasingly vulnerable and began to wane. In 1930, the school was officially shut down. The impact of the School of Islamic Jurisprudence on the Egyptian society, however, was an ongoing one, far outliving the school's closure.

Impact of the School of Islamic Jurisprudence

Even though the School of Islamic Jurisprudence lasted for only twenty-three years, it had continuous and notable effects on the Egyptian society beginning in the first half of the twentieth century. At the educational level, the school put the Azhari ulama under pressure. They were forced to take a critical look at their curriculum and to consider incorporating more modern topics into it, which they did. ${ }^{43}$

In addition to Azharis, Zaghloul chose for the School of Islamic Jurisprudence "different teachers with different educational backgrounds... some of these teachers wore afranji (Western/foreign) outfits, which they were wearing when they graduated from European universities. Teachers with Western education background introduced [to their students and fellows] a new way of thinking and new methods of teaching that were based on observation, analysis, and experimentation...."44 The School of Islamic Jurisprudence, therefore, served as a forum where teachers of different educational backgrounds, conventional and Western, came together and closely interacted. In this 
respect, the school functioned as a medium through which new ideas were channeled to al-Azhar.

The school made another important contribution to development of the Egyptian educational system. When the secular University of Cairo was founded in 1908, the School of Islamic Jurisprudence supported it during its early stages, providing it with the necessary teaching faculty. Suffice it to mention that there were two teachers from the School of Islamic Jurisprudence on the first doctorate committee at the University of Cairo. The doctorate candidate was Taha Hussein (1889-1973), one of the most influential and distinguished Egyptian authors and thinkers of the twentieth century.

Teachers and graduates of the School of Islamic Jurisprudence also played an integral role in generating new intellectual trends in Egypt in the twentieth century. School of Islamic Jurisprudence teachers took an active part in the translation movement flourishing during the period, hence, contributing to the cultural transformation trends in Egypt. $^{45}$

Graduates of the school also contributed to Egyptian culture. Ahmad Amin (1886-1954), a preeminent Egyptian historian, qadi, and an author was a graduate of the School of Islamic Jurisprudence. Amin had served as the head of the faculty of literature at Cairo University, cultural adviser for the Ministry of Education, Director of the cultural department of the Arab League, and a journalist at various Egyptian newspapers. Amin was arguably the first Egyptian historian to write a modern history of the early 
period of Islam. Amin was also the founder of Ladjnat al-ta'lif wa l-tardjama wa-l-nashr (Literary Committee of Translation and Publication). The committee, with Amin being its key contributor, published a large number of works, mainly cultural and educational, that no doubt contributed to social change in Egypt. ${ }^{46}$

Another graduate of the School of Islamic Jurisprudence was Muhammad Abu Zahra (1898 - 1974), a qadi, thinker, scholar of Islam, and an author who published many works on figh. ${ }^{47}$ Students of the School of Islamic Jurisprudence were active at the political level as well, participating in Egypt's political landscape during the first quarter of the twentieth century. Reportedly, students of the School of Islamic Jurisprudence took part in the Revolution of 1919 led by Zaghloul. The students were members of the secret committee of the revolution, and many of them had been arrested on the grounds of their involvement in the event. ${ }^{48}$

To sum up, the ulama and their classical institutions, namely, the shari courts, were not isolated from currents of change that hit Egypt in the course of the nineteenth century and beyond. The creation of a modern state in Egypt, the nature and tendency of this state to spread its control over all activities and regulate them, the need to secure a cover of legitimacy for the newly established state as independent, and the desire to enable the ulama and their institutions to be part of the modern world, all were factors that worked together and contributed to the transformation of the shari justice system. By the turn of the twentieth century, the shari courts and staff were reshaped in a way that made them relate to the modern world. Furthermore, the shari courts and personnel 
became part of the modern state, effectively supervised by it.

How the Egyptian ulama were able to balance the leverage the political authority came to have over them and still to shape the direction of change and to define its boundaries is the main topic of the next chapter. 
Notes to Chapter Three

1. Gabriel Baer, "Tanzimat in Egypt-The Penal Code," Bulletin of the School of Oriental and African Studies, University of London, Vol. 26, No. 1 (1963) 47-49, Farahat, al-tarikh al-ijtimai, 54-55, Aziz Hanki, “al-tashri wa al-qada qabla insha almahakim al-ahliya," in al-kitab al-dhahabi lil-mahakim al-ahliyah 1883-1933, Vol. 1 (Cairo: al-Matbaah al-Amiriyah bi-Bulaq, 1937), 78.

2. Ibid, 78, Shafiq Shihatah, tarikh ḥarakat al-tajdid fi al-nuzum al-qanuniyah fi mișr mundhu ahd Muhammad Ali (Cairo: Jamiyah al-malakiyah lil diradat al tarikhiyah, isa albabi al-halabi), 1961, 46.

3.Sami Amin, taqwim al-nil, vol 3 (Cairo: Al-matbaah al-amiriyah, 1915), 154.

4. Baer, "Tanzimat in Egypt," 48.

5. Sami Amin, taqwim al-nil, vol 3, 1366-1370.

6. Hanki, "al-tashri wa al-qada," 78-79, Barer, "Tanzimat in Egypt," 48-49.

7. Ibid, 48, Sami Amin, taqwim al-nil, vol 3, 1294.

8. Baer, "Tanzimat in Egypt," 49.

9. Layihat tartib al-mahakim al-shariyah wa-al-ijraat al-mutaalliqah biha fi May 28 1897 (Cairo: Al-maṭbaah al-hindiyah, 1897), 3-4.

10. "Al-layiha al- dakhilia lil al-mahakim al-shariyah," al-Mahakim, August 8 and $15,1897$. 
11. "Taqarir min nazart al-haqanyyia bishaan taftish al-mahakim al-shariyah," al Mahakim, May 1, 1898.

12. "Layihat taadib al-qudat al-shariyen, nazart al-haqanyyia, of discolne of shari qadis," al-Mahakim, September 26, 1898.

13. Sami Amin, taqwim al-nil, vol3, 1150, 1196-1197.

14. Layihat tartib al-mahakim al-shariyah wa-al-ijraat al-mutaalliqah biha fi May 17, 1880 (Cairo: Al-mațbaah al-amria, 1880).

15. Layihat tartib al-mahakim fi 1897, 1.

16. Ibid, 5-6.

17.Ibid, 7.

18. Layihat tartib al-mahakim al-shariyah wa-al-ijraat al-mutaalliqah biha fi 1910 (Cairo: Maṭbaah al-ummah, 1910), 37-38.

19. Layihat tartib al-mahakim fi 1897, 2.

20. Layihat tartib al-mahakim al-shariyah fi 1897, 5, 6, 16-19.

21. Ibid, 19.

22. Muhammad Abduh, taqrir fi iṣlaḥ al-mahakim al-shariyah (Cairo: Maṭbaah alManar, 1900), 1-2.

23. Ibid, 1-6. 
24. Ibid, 13-14.

25. Ibid, 13-14.

26. Ibid, 64.

27. Ibid, 65-66.

28. Al-Moayyed, May 16, 1900.

29. Ibid, November 28, 1899.

30. Al-Mahakem, June 21, 1907

31. Al-Mahakem, July 09, 1908.

32. Layihat tartib al-mahakim al-shariyah fi 1910, 65.

33. Al-Ahram, January 18, 1884, March 14, 1888, al-Liwaa July, 31 1904, alMoqatam, October10, 1894, al-Raaed al-Masri, February, 12 1901, al-Moayyed, September 13, 1893.

34. Abd al-Munim Ibrahim al-Dusuqi Jumayi, madrasat al-qada al-Shari: dirasah tarikhiyah li-muassasah talimiyah 1907-1930 (Cairo: Maktabat al-khanji bi-mișer, 1986), 12.

35. Ibid, 13-14.

36. Amir ali bi-insha madrasat al-qada al-shari fi February, 25 1907, dar alwathaak al-qomia, mahafez abdeen, mahfaza 1. 
37. Al-Moayyed, June 01, 1907.

38. Jumayi, madrasat al-qaḍa al-shari, 26-27.

39. Ibid, 15.

40. Mudhakkirat Saad Zaghlul 1857-1927, tahqiq abd al-Azim Muhammad Ibrahim Ramadan (Cairo: Al-hayah al- miṣriyah al-ammah lil-kitab, 1987), karasa 11, October $19,1908,686-68$.

41. Jumayi, madrasat al-qaḍa al-shari, 31.

42. Ibid, 33 .

43. Ibid, 45.

44. Ibid, 23.

45. Ibid, 45 .

46.Ibid,45, Ahmad Amin, Hayati (Cairo: Maktabat al-Nahụah al-Mișriyah, 1961), Fahim, Hafiz Danasuri, Ahmad Amīn wa-atharuhu fi al-lughah wa-al-naqd al-adabi (Cairo: Maktabat al-Malik Fayṣal al-Islamiyah, 1986).

47.Jumayi, madrasat al-qaḍa al-shari, 44.

48. Ibid, 49-51. 


\section{-Chapter Four-}

The Egyptian Ulama in Modern Egypt: Custodians of Change

During a critical period, a transitional phase, that witnessed the making and remaking of modern Egypt, the Egyptian ulama stepped forward to influence the patterns of change, serving, as it were, as custodians of change and guardians of Muslim culture. On the strength of their continuous social influence, their role as the ultimate authority of social conduct, and as validators of political power through public and doctrinal—with political elites recognizing them as a powerful force capable of preserving political legitimacy - the Egyptian ulama were in a position to set the conditions and terms of change and to determine its nature, limits, and outcome.

This chapter first examines an important work that is very relevant to the topic under discussion. This work, "Juristic Authority vs. State Power: the Legal Crises of Modern Islam," is written by Wael Hallaq, a world-renowned scholar of Islam with significant contributions to the field of Islamic legal studies. Hallaq presents the outcome of modern legal reform in the Islamic world as a whole and highlights the factors leading to the results of this development. The examination of Hallaq's study serves as a suitable starting point for outlining the findings and additions of this chapter and of the work as a whole.

Hallaq attempts to elucidate a major legal and political issue resulting from the 
legal reform that took place in the Islamic world during the nineteenth and twentieth centuries. This issue being the crisis of political legitimacy, the most obvious manifestation of which is the popular call to restore the sharia.

Hallaq addresses the crisis of political legitimacy in the context of the emergence of the Muslim modern state. As he observes, one obvious outcome of modern legal reform in the Islamic world, Egypt included, was the transfer of the command of law from the hands of the traditional legal elite (the ulama) to those of the state. For him, this transfer of command represents at once the irretrievable loss of the longstanding epistemic authority of the traditional legal professionals, and the emergence of the authority of the state.

Hallaq first provides a useful historical frame for his argument. He pays close attention to the nature of the relationship between the political and legal authorities on one hand, and the relationship between these two authorities and the masses, on the other.

According to Hallaq, the sharia, or Islamic law, is jurist-made, as it was the jurists who interacted with the sacred sources, comprehended them, and articulated and explained God's law. In this regard, the jurist's authority was "ultimately epistemic in nature, knowing the law and how it is to be derived, interpreted, and applied were the qualities that conferred epistemic authority." This epistemic authority ran through the entire legal hierarchy, from the senior to the minor levels.

Hallaq points out that from an early period in pre-modern Islam, a clear-cut 
dichotomy developed between Muslim political elite and both the religio-legal class and the masses. The jurists concerned themselves with religious and social issues and were a more populist group who established and maintained a close relationship with masses. The Muslim political elite, on the other hand, were isolated from the populace. They were also seen as preoccupied with worldly matters. While the masses looked at the jurists as the ideal of piety, righteousness, and higher education, emerging from within their class and closely related to themselves, the political class represented just the opposite. Infamous, distrusted, and regarded as corrupt, the political class distanced itself from Islamic law and its system, while still respecting it and abiding by it. They generally did not intervene in the legislative process, confining their involvement in legal affairs to the appointment and dismissal of the qadis and the occasional enforcement of the qadis decisions.

Despite the dichotomy, and popular distrust, the political establishment and the ulama, the religo-legal, elite needed each other. Political elites and the ulama learned how to cooperate, although cautiously and from a distance, in order to meet their reciprocal needs. While the ulama relied on royal and government patronage, which constituted the most important source of their income, the ruling body was in dire need of legitimization, which the ulama could confer upon them.

According to Hallaq, the ulama's loss of legal authority to the state was the product of several major developments. First was centralization, namely, when the state embarked on a process of bringing under its direct supervision all major endowments 
along with revenues and assets that supported legal education, and which had been overseen for a long period of time by the ulama. As a result, the ulama started gradually losing their own source of power, becoming heavily dependent on government allocations, which eventually vanished.

The second development that undermined the legal power of the ulama was codification, which Hallaq defines as "a deliberate choice in the exercise of political and legal power, a means by which conscious restriction is placed upon the interpretive freedom of the jurists, judges, and lawyers." Once codification was adopted, conventional methods of determining law were effectively and permanently excluded. With the creation of modern law schools, along with a professional legal body that took over the traditional ones, coupled with the introduction of Western-style legal codes and institutions which displaced Islamic law and its system, "the demise of sharia was assured by the strategy of 'demolish and replace'."

The third development that undermined the legislative power of the ulama involved the shift in authority to the state. Certainly, modern legal reform shifted legal control from the ulama to the political class. This development is responsible for the legal and political crisis in the contemporary Islamic world. However, Hallaq's explanations of this transfer and its effects on the ulama are irrelevant to the Egyptian situation. According to Hallaq, the transfer of legal authority to the state was "sudden," and achieved by means of "force" and "coercion." By the onset of the modern reform, Hallaq affirms, the ulama, or the traditional legal elite as he calls them, were disabled, 
effectively weakened and bankrupt, and either chose, or were forced to, step aside and withdraw from the new reality, with which they were incapable of dealing.

As has been shown in the previous chapters, unlike other parts of the Muslim world, modern legal reform in Egypt was neither sudden, nor was it devised to displace the sharia. Rather, the purpose of legal reform was to supplement the sharia.

Chapter two in particular has shown that the Egyptian government, utilizing and expanding the legal rights that the sharia grants to the Muslim ruler, namely, the concept of siyasa, was able to make fundamental changes to the existing legal system, introducing Western-inspired legal entities and concepts based on this right. Hallaq, however, minimizes the significance of this concept, dismissing it as "no more than episodic regulations promulgated by the [Ottoman] Empire..." This conclusion is irrelevant to the Egyptian case either.

In light of the new information obtained from the Egyptian National Archive, chapter four further demonstrates that while the Egyptian government also commandeered the law, it explained and justified its new role as a legislator and accounted for the introduction of Western legal categories from a shari perspective. Stated differently, the information at hand shows clearly that the Egyptian political elite took on the mantle of legal authority under a cover of Islamic doctrinal legitimacy. This cover came from within the Egyptian ulama circles. Using Islamic doctrinal legitimacy along with certain rights given to the Egyptian ruler, Egypt acted as an independent state, 
developing its own distinct legal system.

Another, more important reality this chapter stresses is that what is regarded by scholars as the most obvious vulnerability of the Muslim nation-state, namely its disconnection with, and isolation from, its subjects is what made, and continued to make, the ulama indispensable in Egypt.

Throughout his article, Hallaq is cautious about his usage of the term "modern Muslim nation-state." He points out that the notion of modern nation-state cannot be completely applied to the types of political bodies that emerged in the Islamic world in the aftermath of modern legal reform. Chief among the reasons is that, unlike its European counterpart, the modern Muslim nation-state "has not commanded, nor it is likely to command, the conformity of the Muslim masses to its will, much less their respect."

Hallaq observes, "It was one of the salient features of the pre-modern Islamic body-politic that it lacked systematic control over the infrastructures of the civil populations it ruled." In pre-modern times, the ulama served as a bridge between the rulers and the masses from whose ranks the ulama emerged and whom they served and represented. Thus, the ulama were "often called upon to express the will and aspirations of those belonging to the non-elite classes. The ulama did not only interact on behalf of the people at the higher reaches of power, but also represented for the masses "the ideal of piety, rectitude, and fine education." The ulama's role as "Guardians of Religion, 
experts in religious law and exemplars of virtuous Muslim lifestyle made them not only the most genuine representatives of the masses, but also the true "heirs of the Prophet," as one prophetic report came to attest."

Hallaq, nevertheless, asserts that in terms of generating authority, the ulama' social roles were merely supportive, only improving the ulama's image "as both the custodians of the Sharia and the unfailing civic leaders of the Muslim communities."

As Hatina has observed, during the Urabi episode (1881-82), the Egyptian ulama demonstrated communal vitality, impressive mobilization capacity, along with an ability to challenge or confer and confirm the political legitimacy of the ruling elites. This observation testifies to the fact that in the course of the nineteenth century, the Egyptian ulama remained a powerful social and political force in the public arena.

As the two important historical episodes examined below will show, the social influence of the Egyptian ulama, demonstrated in the form of public, religious assertiveness, was the main source of their authority and significance. Among many other things, social influence helped the ulama in the long run to maintain and restore their function as legitimizers of political power and state policies. On the strength of their social influence, the Egyptian ulama were able to impact the political elites and to force them to adjust to the ulama's state of mind, hence, significantly influencing patterns of change in modern Egypt. 
The Episode of May 1899

The episode of May 1899 illuminates that even though the shari justice system was brought under direct state supervision, the ulama defended and maintained their function as the ultimate authority over deciding and handling the shari law. The event illustrates how both the Egyptian ulama and the political elites negotiated power and how the former resorted to religious assertiveness in the public sphere to counterbalance the leverage that the modern state had over them. The episode of May 1899 also shows that Egyptian political elites bowed to the sharia and subordinated themselves to it. When arguing against the ulama, state officials based their counterarguments on Islamic religious grounds. Last, but not least, the episode of May 1899 illustrates the role of the Egyptian ulama in modern legal reform.

Due to the significance of this event and how self-evident it makes the impact of the ulama and the subordination of the political elites to sharia, the presentation of the episode will be more descriptive than analytic.

The Episode

On May 10, $1899^{2}$, majlis shora al-quaneen held an important meeting to discuss a controversial reform proposal backed by the Egyptian government. Majlis shora alquaneen was a government legislative entity. The legislative process involved a number of steps that majlis shora al-quaneen would take in order to pass a proposed law. These 
steps included assessing, amending, and voting on the proposed legislation.

The government-backed proposal under consideration sought to introduce changes to the makeup of the personnel of the High shari Court of Appeal. It proposed hiring two qadis from the National Court of Appeal (a secular court) to assist the staff of the High shari Court of Appeal in the adjudication process.

Due to the significance and sensitivity of the matter under consideration, the meeting was attended by the highest level of both state officials and the ulama. Chaired by the president of majlis shora al-quaneen, the meeting was attended by 24 members of the majlis; the Prime Minister, Egypt's top legal adviser, all cabinet ministers except ministers of labor and education, and two senior ulama: Jamal al-Din Effendi, the qadi of miser, and Sheikh Hasona al-Nawawi, the Grand Mufti.

At the outset of the meeting, the head of the majlis shora al-quaneen stated that the purpose of the meeting was to discuss a revised version of a proposed high decree that was previously presented to the majlis. The majlis had rejected the first draft of the proposed high decree. The government then modified the decree in a way that rendered it more acceptable and generated a report addressing the reasons the majlis had dismissed the previous version of the proposed high decree.

The Egyptian government's response unequivocally demonstrates that the emergence of the modern state in Egypt as legislator and commander of the law in the early twentieth century was explained and justified on Islamic religious grounds. 
The Ulama Critique of the Government's Initial Proposal

The government report submitted to the majlis began by outlining the two reasons that had compelled the ulama, the qadi of miser and the Grand Mufti, to adamantly oppose the government-backed reform. The first reason concerned competence and qualification: the ulama believed that the qadis of the National Court of Appeal were not qualified to try shari cases. Both the qadi of miser and the Grand Mufti maintained that according to the sharia, it was prohibited to authorize someone unable to distinguish between al-qaul alrajeah (a legal opinion based on solid and explicit textual evidence) and al-marjoah (a legal opinion based on an interpretation of the text) of the great hanfi madhab. For the ulama, he who was to adjudicate according to the shari rules must be able to judge and issue fatwas according to the sound opinions of Abu Hanifa and must be experienced with shari rules of trial procedures as well. Here, the ulama were stressing their epistemic authority and their longstanding position as experts in the sharia.

The second reason for the ulama critique of the proposal was both legal and political. As indicated in chapter three, the Khedive's right to appoint the qadi of miser was not explicitly granted. The qadi of miser and the Grand Mufti found in this, implicit grounds to challenge this right. They argued that the qadi of miser was appointed by the Great Caliphate, the Ottoman Sultan. To allow one of the qadis of the National Court of Appeal to share (the legal authority and adjudicate side-by-side with) the qadi of miser 
was not permissible according to the sharia.

The core of the matter was not whether the Egyptian ruler had the right to appoint the qadi of miser or not. Rather, permitting two qadis from outside the ulama circles without their permission was the crux of the issue. Challenging the Egyptian ruler's right seems to be a tactic to bargain and to negotiate. Certainly, contesting this right demonstrates ability of the Egyptian ulama to confer and confirm legitimacy or to deprive it at will.

The Government's Response

In response, the Egyptian government first clarified that the two qadis intended to be hired to try cases in the High shari Court of Appeal would certainly be adequately acquainted with the shari rules, which would make them qualify to serve in this court. Thus, hiring these two qadis was made in accordance with the shari rules. As for requiring that any appointed qadi must be experienced with the shari rules of procedures, the Egyptian government dismissed this justification on the grounds that it was the government's right and role, and not anyone else's, to ensure that these administrative qualifications were being met.

The nazer al haqqanyia (minister of justice) interrupted delivery of the report to offer his comments on the issue of qualification. He pointed out that most of the qadis of the National Court of Appeal graduated from the school of law. Graduates of this school 
had taken classes in the sharia. In addition, students of the school of law passed exams in the sharia before obtaining graduation certificates. Nazer al haqqanyia argued "If we suppose they [graduates of the school of law] do not know all the shari rules, they, at least, know the [shari] rules concerning personal law, to which the jurisdiction of the shari courts is limited."

Resuming with report, the Egyptian government clarified that the qadi of miser and the Grand Mufti were not completely aware of the premises of the reform proposal. They did not seek clarification from the nazer al haqqanyia. Therefore, "they mistakenly concluded that the reform plan was in disagreement with the honorable sharia, even though nazer al haqqanyia made the proposal in accordance with its principles." The Egyptian government also explained that the nazer al haqqanyia did not make any changes to the existing shari legal system. Rules and procedures of this system were established by a decree from the Khedive issued on May 27, 1897. This decree was accepted by the qadi of miser who had since then complied by it. "What this proposal basically sought was putting two court members in the place of others, so how this could be seen as a violation of the sharia since the qadis they intended to hire possessed alAlamayia, " the Egyptian government argued. The Egyptian government added that:

It was the Grand Mufti and the qadi of miser themselves [who were the addressees of the report] who made this a requirement for the appointment of the qadis in the shari courts. Because the qadi of miser and the Grand Mufti were not completely informed about the basis and objective of the reform proposal, they invoked a discussion about a sensitive matter concerning the rights of the Sultan and the Khedive to appoint the qadi of miser, an issue that we are forced to discuss. 
Addressing the ulama's second concern, whether the Khedive possessed the right to appoint the qadi of miser, the Egyptian government put forth a well-constructed and complex counterargument supported on shari grounds and explanations, as well as precedents. Referring to such highly-influential and widely-respected works on fiqhas Radd al-Muhtar ala al-Dur al-Mukhtar, the commentaries of the distinguished scholar Ibn Abdidin, the Fatawa al Hindiyya, Maain alhkam, and Ktab Al-Ahkam al-Sultaniyya, the Egyptian government first outlined the types of wilayah (guardianship), as well as the scope of each category. It then specified which one of these categories the Khedive actually possessed. According to the aforementioned works. the wilayah of Muslim rulers are of two types: wilayah umma (unlimited guardianship), which involves legal right to determine the criteria based upon which qadis would be appointed, and wilayah kasaa (limited guardianship), which does not include the same legal privilege and authority.

For the Egyptian government, the wilayah of the Khedive involved the exercise of legal authority over the shari legal system in the Egyptian land; the Khedive possessed alwilayah al-umma, and reserved the right to appoint all shari qadis in Egypt, and this was one of his shari rights. The Egyptian government then provided grounds for the claim that rulers of Egypt had al-wilayah al-umma. It should be noted that in its efforts to prove the Khedive's possession of al-wilayah al-umma, the Egyptian government heavily depended on the recognition of the senior Egyptian ulama of this claim, as well as shari grounds backing it.

According to its own account, the Egyptian government used to appoint on its 
own all qadis in Egypt, except the qadi of miser. The latter was appointed by the Ottoman government every year by a faraman. This process remained until the ascendance of Ismail Pasha (1830-1895). During Ismail's reign, the Ottoman government ceased issuing faramanat of appointment to the office of the qadi of miser. At the same time, a committee consisting of senior Egyptian ulama was formed to elect the qadi of miser. Among these ulama was the Grand Mufti of Egypt, sheikh Muhammad al Abbasi, and sheikh al-Azhar. Having convened and deliberated the matter, the ulama committee nominated a qadi for the office of the qadi of miser. Immediately, the Khedive accepted the ulama's recommendation, single-handedly and with no consultation with the Ottoman government, his command to appoint this qadi as the qadi of miser. The Khedive, on the basis of his wilayah umma, authorized the newly appointed qadi to preside over the shari legal system in Egypt.

Sheikh Abdulrahman Nafez Effendi was made the qadi of miser. He remained in office for more than fifteen years. During this period of time, Nafez and his fellow members of the High shari Court of miser made a variety of decisions and verdicts that were deemed sheikh Muhammad al Abasi, the then Mufti of Egypt, sheikh al-Azhar, and the ulama as a whole. Testifying to the fact that Nafez's decisions were considered sound was that al-Fatawa al-Mhadiya (the proclaimed work of sheikh Muhammad al Abbasi, one of the most important fatwa collections of the nineteenth century) endorsed and ratified many of these decisions. Nafez was regarded by the senior ulama of Egypt as qualified and competent. His decisions were recognized as sound. If, the government 
argued, the ulama were skeptical of the Khedive's right to appoint the qadi of miser, they would have not recognized and endorsed verdicts and decisions Nafez made as valid. That is to say, the Egyptian government maintained that Nafez was appointed by the Khedive, directly deriving his legal authority from him and adjudicating on his behalf. If the Khedive did not possess the right to appoint the qadi of miser, this would render all decisions and verdicts Nafez made invalid and vice versa.

After the death of sheikh Abdulrahman Nafez, the Egyptian government followed the steps of Ismail Pasha and elected, on its own, a successor. Tawfik Pasha (1879-1892) appointed Jamal al-Din Effendi, Nafez's son, the qadi of miser present at the May 1899 meeting, as the presiding qadi over the shari legal system in Egypt. "But what is the basis of his [the Khedive] wilayah umma over Egypt?” the Egyptian government asked. It explained that all fiqh books, including the ones mentioned earlier, divided legal terminology of appointment into two kinds. The first type was explicit, which did not need presumptive evidence to back it, such as saying, "I made you in charge of the judiciary," "I appointed you as a qadi," and so on. The second type was implicit, which required presumptive evidence to support it and to define its meaning. The presumptive, implicit evidence outlined by the Egyptian government demonstrating that the Khedive possessed wilayah umma follows.

First, argued the government, the precedent of appointing sheikh Abdulrahman Nafez Effendi as the qadi of miser. The appointment was made based on the Khedive's wilayah sharaia umma. Abdulrahman Nafez Effendi held the office of the qadi of miser 
for over fifteen years, during which he reached verdicts and made decisions that were neither contested nor rejected by the Ottoman government and the Egyptian ulama. Following the death of Nafez, the then Khedive appointed Nafez's son as the qadi of miser.

The second piece of presumptive evidence, argued the government, all Ottoman faramanat, especially the one sent to the Khedive Twafiq Pasha, indicted that the Khedive possessed al wilayah sharaia umma. The faraman sent to the Khedive Tawfiq Pasha stated that "the Khedivate of Egypt is bound to manage political, financial, and judicial affairs of the realm of Egypt." In addition, the faramanat in question explicitly authorized the Khedivate to enact regulations and laws in Egypt. Third, the Ottoman government gave away to the Khedive the tradition/right of issuing recognition faramanat of counselors of foreign countries in Egypt.

Fourth, since the appointment of Nafez, not one single Ottoman faraman had been issued appointing the qadi of miser, as used to be the custom prior to the appointment of Abdulrahman Nafez by the late Ismail Pasha. Fifth, article 4 of the LTMS of 1880, which was formulated in consultation with the late sheikh Muhammad al Abbasi, sheikh alAzhar and the Mufti of the Egyptian lands, as well as Abdulrahman Nafez Effendi, the then qadi of the High shari Court of miser, made electing and appointing the qadi of the Egyptian capital exclusive to the Khedive.

Sixth, argued the government, the current qadi of miser agreed to the Egyptian 
government's authority over, and role in, the shari legal system. According to the privilege given to it, the Egyptian government had unrestricted authority over the shari judicial system. This legal right, which the Khedive gave to the Egyptian government, could only be granted by someone who possessed the right to appoint the qadis in Egypt.

Seventh, the current qadi of miser agreed that qadis receiving their legal power exclusively from, and appointed by, the Khedive would try legal cases side-by-side with him. The qadi also agreed to adjudicate in accordance with the LTMS [of 1897]. The LTMS of 1897 established the majority rule process, which did not require consensus for group action. Rather, decisions were to be made by voting with a majority, and not one qadi alone, determining the position of the entire group. The current qadi of miser therefore accepted that he might be among the minority in the decision making process. Decisions made and passed by the majority, whether or not they were in agreement with his opinion would not prevent the decision from being concluded and passed. Since the qadi of miser agreed to this sharing of his legal authority, abided by this regulation, and since these legal procedures were introduced by the Khedive, it was a contradiction to say that the source of the qadi of miser's legal authority was the Great Caliph of the Ottoman Empire rather than the Egyptian Khedive.

Eighth, the al-Fatawa al-Mhadiya, addressing matters surrounding the issue in question, made clear that the Egyptian khedivate possess wilayah qadaia in Egypt. In closing this eight-element argument supporting the right of the political power 
to appoint qadis, the Egyptian government pointed out that the basis upon which the current qadi of miser was appointed was solely the decree issued by the Khedivate of Egypt on April 1, 1891, based on his wilayah umma. According to his wilayah umma, all shari qadis in the Egyptian provinces were appointed by the Khedive, hence, received their legal authority from him. These qadis were just as competent and authoritative as the qadi of miser. Also on the basis of his wilayah umma, regulations of the shari courts were enacted, and a panel was created in the High shari Court of miser to adjudicate sideby-side with its qadi. Members of this panel were equally competent to the qadi of miser.

The ulama recognized and agreed to the latter measure, without invoking opposition whatsoever. This preponderance of evidence demonstrated, clearly, that the two reasons leading to the rejection of the government's reform proposal were not valid. In principle, "this is not a rejection of the proposal per se. Rather, it is a denial of a half century of legal tradition in Egypt." As for the Khedive's claim to have the necessary legal power to authorize the qadis that the government intended to hire to try in the High shari Court of Appeal, since these two qadis were to be authorized by the Khedive, the source of the legal power of every single qadi in Egypt, the qadi of miser's claim to have legal power to authorize qadis in Egypt to adjudicate had no foundation.

The Foreign Minister's Argument

The ulama attending the meeting remained silent until the nazer al-kharijia (foreign 
minister) addressed the issue of the Khedive's wilaya umma in Egypt from a political perspective. To substantiate that the Khedive possessed wilaya umma, he referred to the Ottoman faramanat. He said that these faramanat stated clearly that the Khedive had the right to oversee financial, administrative, and legal affairs of Egypt. He pointed out that the term legal was equivalent to the term Adila commonly used in Istanbul. Adila was equal to the term Haqqanyia frequently used in Egypt.

Jamal al-Din Effendi interrupted to clarify that "The word Adila mentioned in the faraman refers to state courts [secular courts]," and not the shari courts. Nazer al-kharijia responded by saying that "The meaning of the word Adila in French is Haqqanyia, which is judiciary." Jamal al-Din Afindi replied by stating that "The faraman is in Turkish, and not in French." The nazer al-kharijia weighed in, "Jamal al-Din Effendi is acquainted with French, which is the official language of translation in the Ottoman state, and [we find] in the translation of the faraman the term judicial matters. If the shari judicial system was not part of Egypt's overall legal system, it would have been exempted by a clear statement. According to this judicial right [of the Khedive], the government enacted laws, that is to say, regulations." Jamal al-Din Effendi and Sheikh Hasona, responded jointly, "Laws cannot be enacted for the sharia." The nazer al-kharijia stated laws could not be enacted for the sharia and clarified that "Neither I, nor anyone else have spoken to this. Laws which the Khedive has the right to enact concern case management, procedures, and court administration and function, which do not disturb, even slightly, the sharia." On the basis of this right, he went on: 
[T] he Mixed Courts were created in the country [Egypt], trying both Egyptians and Europeans in the name of the Khedive... which in itself is enough evidence, politically speaking, demonstrating the Khedive's wilaya umma. In addition, the Egyptian government established the National Courts, authorizing these courts to adjudicate, in the name of the Khedive, all legal matters, except those of personal statute. It is not overstating the fact that the shari courts are [by now] competent only in matters of personal status. Is it logical, from a political point of view, that the Khedive has the right to appoint a qadi [in the National Courts] authorized to pass a death sentence, while he [the Khedive] does not have the right to appoint a qadi to try matters of personal status [?]

The nazer al-kharijia then turned to address the claim that Jamal al-Din was appointed by the Ottoman Sultan, and not the Egyptian Khedive. He reiterated that in the past, the qadi of miser used to be appointed by the Ottoman government for one year in this office. Latter, however, it was decided that Egypt would pay the Ottoman government in exchange for granting the right to appoint the qadis of the provinces and governorates. What remained to Istanbul, argued the foreign minister, was merely the right to appoint a qadi for the city of miser.

Since the appointment of the late sheikh Abdulrahman Nafez as qadi of miser, the Ottoman government stopped sending qadis and faramanat of the appointment to the office of the qadi of miser. This was so because the Egyptian government obligated itself to paying a specific amount of money every year to the qadi appointed by the Sultan in exchange for keeping this person in Istanbul. This had been the custom ever since.

The nazer al-kharijia suggested that if Jamal al-Din was appointed by Istanbul as the qadi of miser in the year in which he arrived in Egypt, his mandate as the qadi of miser must have been expired by the end of that year. He added that throughout the years 
following the year in which Jamal al-Din was appointed, the Egyptian government had been paying Istanbul the agreed upon amount of money for the right to appoint the qadi of miser. The rule in Istanbul, which remained in effect until the appointment of sheikh Abdulrahman Nafez Effendi, was that the qadi would stay in this office of the qadi of miser for no longer than one year.

The nazer al-kharijia concluded that the qadi of miser was not, and could not, be appointed by Istanbul, and that the Khedive secured the right to appoint all provincial qadis and the qadi of miser. For this reason, the late Ismail Pasha was able to issue a decree appointing Abdulrahman Nafez as the qadi of miser, indicating in the decree of the appointment that he possessed al wilayah al-umma, and that Jamal al-Din Effendi was to only preside over shari matters in the Egyptian land, and not the entire legal system in the country.

The nazer al-kharijia then went on to address the matter of whether the qadi of miser had the right to permit other qadis in Egypt to adjudicate. He pointed out that the right to authorize qadis, even though it was a shari issue, was one of the most important political matters, since the absence of this power would undermine possession of al wilaya al motlaka (unlimited guardianship).

The nazer al-kharijia then presented a copy of the telegraph that included the agreement reached between the Egyptian and Ottoman government concerning appointment of the qadi of miser. Citing the telegraph, the nazer al-kharijia stated that it 
was decided that an amount of 250 Ottoman lira (Ottoman currency) was to be paid every month to the qadi yearly appointed by the Ottoman government as the qadi of miser in exchange for keeping this qadi in Istanbul. A naib of him to occupy his position in Egypt was to be elected by the Khedive and appointed by a faraman."

The Ulama's Response

Jamal al-Din Effendi interrupted the nazer al-kharijia to clarify that "The meaning of the word astensab (choosing something/someone suitable, fit) mentioned in the telegraph does not suggest [authorizing] Egypt to elect [the qadi of miser] on its own." The nazer al-kharijia responded with saying that the telegraph did indeed contain the word intikab (elect-select), and that it was one of the Khedive's rights. "If we suppose, contrary to what is obvious in the telegraph, that electing [the qadi of miser] is one of Istanbul's rights, then what is the meaning of the word astenssab?," Nazer al-kharijia posed. "Does not astenssab mean intikab, which is giving the Khedive the right to choose whoever he deems suitable to the office of the qadi of miser[?]" He then argued that:

If we are to comply with the aforementioned agreement, the qadi of Egypt must be a naib [a substitute judge of the principle judge remaining in Istanbul], and he is to be appointed by a faraman. There was no faraman delivered concerning the appointment of the current qadi. He has not been authorized by the qadi appointed [by the sultan] every year. We do not see in all his judgments [Jamal al-Din effendi's] any reference to this permission or the name of the original qadi.

Taking the discussion to the core of the matter, Jamal al-Din Effendi stated that: 
"Regardless of who has the right to authorize [qadis in Egypt] to adjudicate, we consider whether or not it is permissible for two qadis from the National Courts to adjudicate in a shari court. This is not permissible."

Sheikh Hasona al Nawawi then took turn to offer his views on the matter. Al Nawawi pointed out that when the first draft of the reform proposal was presented to the majlis earlier,

we explained the functions of the High [shari] Court and showed that most of the cases brought to it involved fatwa. Needless to say, the High [shari] Court is the highest [shari] court in Egypt, and many of the most distinguished figures resort to it. Therefore, we insisted that those who adjudicate in this court must be experienced with the shari methods of trying in order to be able to distinguish between the sound [opinion] from the unsound one. Two [persons] cannot disagree about [the importance of] this [requirement]. In addition, he [any potential member of the High shari Court] must be reliable. The qadis of the National Court of Appeal adjudicate [cases involved] usury and other matters prohibited by God. Thus, I do not agree that it is permissible to hire qadis [from these courts] to try in the shari courts. Nazer al Haqqanyia and the legal counselor maintain that appointing the qadis is one of the Sultan's rights which he passed to the Khedivate... and this qadi [Jamal al-Din] is saying to me that he was appointed by the Sultan and I believe him. The government should have asked me [in advance] about this proposal so that we could have agreed [on a reform proposal] that does not disrupt the sharia... If there is a political issue, it is not our job to address it, but the government.

The Prime Minister then commented with saying that "It seems that the

government's fault to sheikh Hasona is that it did not consult with him first about this

proposal.” Sheikh Hasona said that:

It has been said that a group of ulama stated that this proposal is in agreement with the sharia. Who are the ulama who said so[?] We have indicted the sources based on which our perspective was grounded. Since I am the mufti of the Egyptian land and the one who must be consulted about shari matters, it is not proper to consider anyone else's fatwa concerning a 
proposal as such." Al Nawawi then affirmed that "What I am saying is that this proposal is against the sharia and I absolutely reject it...

Jamal al-Din Effendi followed suit and declared that "I reject this proposal because it is against the sharia." When asked that "The qadi [of miser] and [the Grand] Mufti said that appointing two qadis from the [National] Court of Appeal is not permissible since these qadis try according to a legal system in which usury is legal. If the government appoints other different qadis, will this be agreeable in principle?" Jamal al-Din Effendi answered that "If they are from among the ulama and were elected by a committee, with my presence and opinion, they can try after receiving my permission [to do so]."

Sheikh Hasona al Nawawei, confirming Jamal al-Din Effendi's position, stated that "If they are from among the ulama teaching [at al-Azher] who possess al Almyya, then they can try after receiving the qadi of miser's permission, since, as this qadi says, he was appointed by the Caliph, and as such, he has the [ultimate] word in shari matters."

Because the Grand Mufti and the qadi of miser denounced the modified reform project, most members of the majlis followed suit. As government officials left the meeting, the majli members began casting their votes on the reform proposal. The reform project was rejected by the majority: 20 members voted against it, with only two members reserved voting.

Taking the Dispute to the Public 
On May 21, 1899, eleven days after the meeting, the official Egyptian newspaper published a copy of the proposed high decree, which the majlis had voted overwhelmingly against. The Egyptian government ordered that the reform be put into effect. $^{3}$

In response, Jamal al-Din declared that the Egyptian government, by deciding to go through with the controversial reform plan, had absolutely violated the sharia. ${ }^{4}$ The Grand Mufti followed suit and issued a fatwa in which he condemned the government's initiative, announcing that it was immoral and incorrigible. ${ }^{5}$ At the same time, a number of notable ulama gathered at the house of Abd al Kader al Refaai, sheikh Rewaq al sham (teacher of the shami division) in al-Azhar and the president of al majlis al almi (scholarly council) in the High shari Court of miser.

Following the meeting, the ulama sent a petition to the Khedive urging that "the government may not violate the boundary of the sharia by pursing the newly [introduced reform] proposal, which is in contradiction with the shari rules." The petition was signed by 43 alim. ${ }^{6}$ Ulama of al-Azhar also submitted petitions to the Khedive in which they complained about the new reform project, urging that the Khedive intervene and reverse it. ${ }^{7}$ In addition, Egyptian notables and merchants sent letters to the Khedive requesting that "the shari legal system be protected from any action that will upset the sharia and its rules." "It was also reported that Lord Cromer, the British consul general in Egypt, traveled to Alexandria where he met the Khedive and recommended that the Egyptian 
government not follow up with the disputed reform proposal.

Overwhelmed by the opposition, the cabinet held a special meeting to contemplate the situation and decided that the high decree authorizing the Egyptian government to hire the two qadis from the National Court of Appeal be reversed. At the same time, the head of the opposition, Hasona al Nwawai, was dismissed from both his post as the Grand Mufti and his position as sheikh al-Azhar. Muhammad Abduh, who was then a qadi in the National Court of Appeal, was appointed after him as the new Grand Mufti of Egypt. The cabinet also decided that the nazer al Haqnaya would work closely with the newly appointed mufti of Egypt to put forth an agreeable reform plan for the shari courts. Shortly thereafter, the nazer al Haqnaya commissioned Muhamad Abdah to investigate the condition of the shari courts all over Egypt and submit a report comprising the results of his investigation (see chapter three). ${ }^{9}$

May 1899: Conclusion

Several conclusions follow from the re-examination of episode of May 1899. The Egyptian government, in assuming the role of legislator and commander of the law, was acting under a cover of legitimacy. This cover was recognized and had been backed by the Egyptian ulama. Egyptian regimes and rulers continued to respect the sharia and behaved as subordinate to it. That the Egyptian ulama were made state bureaucrats and that the shari courts were brought under direct state oversight did not affect their 
longstanding function as the experts in the sharia, or their epistemic authority. Moreover, and perhaps more importantly, the episode of May 1899 shows that the Egyptian ulama, through the exercise of religious assertiveness in the public sphere, could challenge the political elites and compel them to adjust to the ulama's mindset. The second important historical event, the case of sahib al-Moayyed, examined below will further consolidate these conclusions.

The of Case of Sahib al-Moayyed

The case of sahib al-Moayyed (sahib means owner and al-Moayyed is the name of one of the most influential Egyptian newspapers at the time) is another event of legal and social importance in Egypt. It captured public attention, as well as that of the authorities at almost all levels. Essentially, the case of sahib al-Moayyed presented the question of whether a Muslim Egyptian women could conclude marriage on her own without the permission of her guardian, her father. In considering the case, interpreting the texts and applying the law, the Egyptian ulama showed a great deal of inflexibility, despite pressure from the state's highest authorities to alter their position on the case. The relentless stance the ulama maintained toward the case of sahib al-moayyed should be seen as the product of the circumstances of the period, the turn of the twentieth century, rather than the outcome of a blind and rigid interpretation and application of the law.

As Zaman observed, when interpreting the texts, the ulama of the late nineteenth- 
and early twentieth-century Pakistan were prepared to dictate hardship on Muslim individuals by their inflexibility. In doing so, the ulama were stressing the old tradition of individual-to-individual transmission of knowledge in Islam and the notion that religious texts could be accurately comprehended solely by those who were ijaza (authorized) to interpret these texts. $^{10}$

Behind this emphasis on the part of the ulama was a sentiment that to assign texts as authoritative for reasons of judicial practice was inadequate. The validity of this practice would entail that "the right people interpret those texts." The case of sahib alMoayyed, therefore, was an opportunity for the Egyptian ulama to emphasize the continuation of their longstanding position as the Guardians of Islam and the only experts in the family law.

Another important factor leading to the inflexibility of the Egyptian ulama in interpreting and applying the law was the perceived invasion of Western cultural norms, threatening to change, or destroy, Muslim family structure, the basic unit of Muslim society. Sahib al-Moayyed took place during a period that witnessed vigorous attempts by Egyptian intellectuals impressed by Western culture to promote the adoption of Western cultural values of women's liberation and the pursuit of equal rights between men and women. For the ulama, embracing such values would lead to undermining the authority of the family, particularly the father, over its members, specifically the women.

The call for gender equity was seen as constituting a serious threat to the cohesion 
and stability of the Muslim family as well as to Islamic cultural norms and principles as a whole. The ulama were not prepared to consider alterations to the social structure in light of such Western ideals, and they could argue that society might not have been ready to embrace such values.

All in all, the case of sahib al-Moayyed offered the Egyptian an opportunity to stress their long-standing position as the guardians of Muslim culture, the only experts in family law, and the ultimate authority of social change. It was a chance for the ulama to define the lines beyond which change must not be pushed.

Sahib al-Moayyed: Events

As the narrative of the case of sahib al-Moayyed goes, sheikh Ali Youssef was the owner and the editor in chief of al-Moayyed, one of the most popular and influential daily Egyptian newspapers at the time. Youssef was born to a poor family and raised in a remote little town in al-Saaid (upper Egypt). He later immigrated to Cairo to pursue his education at al-Azhar. As he became a famous writer, publishing in the most respected and widely-read newspapers, he left his studies at al-Azhar and chose to work as a professional journalist. He then founded his own newspaper, al-Moayyed. Youssef's successful career as a journalist brought him wealth and fame. Sooner, he became well connected, establishing close friendships with many of the most influential figures in Egypt, including the Khedive himself. 
While visiting Istanbul in the summer of 1902, Youssef happened to come into contact with one of his friends, Ahmed Abd al-Khalek al-Sadat, a member of one of the most highly-esteemed families of Egyptian nobility, being of the line of the Prophet. Sadat was visiting Istanbul accompanied by his youngest daughter, Safia. Youssef immediately fell in love with her. He posed the question of marriage, but Sadat declined. After the intervention of a number of highly-influential figures, Sadat reportedly agreed to the fiancée arrangement.

Sadat, however, kept postponing the marriage, always finding excuses to do so. At the same time, Youssef and Safia had been exchanging love letters. Frustrated by Sadat's endless delay to conclude the marriage, Youssef, as Safia turned eighteen, privately arranged with her to get married without her father's knowledge or permission. ${ }^{11}$ On Thursday, July 14, 1904, Safia, accompanied by relatives sympathetic to her case, met Youssef and concluded the marriage at the house of Mohammed Tawfiq al Bakri, sheikh al mashaikh of the Sufi orders in Egypt, a relative of Sadat, and Safia's brother-in-law.

Sadat woke up the following morning to news of the marriage, reported by the Egyptian daily newspapers. Immediately, Sadat decided to take legal action. He rushed to the police station where he filed a lawsuit against Youssef, accusing him of misleading his little daughter and concluding the marriage behind his back. The prosecutor, however, dismissed the case on the grounds that Safia was obviously an adult, able to conclude marriage on her own according to the sharia. Sadat did not give up. He turned to the shari 
court where he pleaded that the marriage of Youssef and Safia was invalid because it did not meet the shari rules specified by Abu Hanifa, demanding that the marriage be dissolved on these shari grounds. ${ }^{12}$

Sahib al-Moayyed: The Case

Unlike other madahbs, the founder of the hanifi madahb permitted the adult woman to marry without the permission of her guardian, provided that she was of age, of sound mind, and the chosen man was suitably equal to her social status. In a situation where the woman contracts a marriage without the consent of her guardian, the latter has the right to question the husband's suitability. If the man, according to popular opinion and evaluation, is inferior to the woman, her guardian can request from the qadi the nullification of the marriage contract. Basic suitability requirements as specified by Abu Hanifa, which are applicable only to men, include: lineage, Islam, free status, financial suitability, higher education, piety, and occupation. A man whose family line is subordinate to that of a woman is not suitable for her. A Muslim man whose father was a non-Muslim is not suitable for a woman whose father is Muslim. A man who is free, though his father was a slave, is not suitable for a woman whose father is free. Financial suitability means that the husband must be capable of meeting the expenditures and dowry appropriate to the status of the intended wife. An alim (graduate of al-Azhar) is automatically suitable for a woman. The occupation of the husband must be equal to that 
of the wife's father and not one of which the husband would be ashamed. ${ }^{13}$

Referring to the aforementioned requirements of suitability, Sadat argued that Youssef did not meet these provisions, hence, his marriage contract with Safia was invalid. On July 25, 1904, the shari Court of miser held the preliminary hearing in the case of sahib al-Moayyed. Both Sadat and Youssef sent representatives to act on their behalf. Safia, however, did not send a representative to court. Sadat's representative was the first to speak and formally made the charges. He claimed that the marriage contract of Youssef and Safia was invalid because the marriage was concluded without Sadat's knowledge and permission., and that, in particular, Youssef was not equal to Safia. Youssef's representative, denied this claim, stressing that Youssef was equal to Safia, and that Sadat's permission to conclude the marriage contract was not needed, since, according to Abu Hanifa, Safia was of age and mature, thus able to conclude the marriage contract on her own.

By the end of the hearing, the qadi ruled that Safia be separated and returned to her father's house until a decision concerning the case could be made. ${ }^{14}$ Youssef and Safia, however, refused to abide by court order and contested it. The government, for its part, kept postponing implementation of the decision.

A second hearing took place the following day, July 26. As the case was increasingly capturing public attention, a massive crowd attended this hearing. Reporting from the courtroom, an al-Moayyed correspondent stated that: "The courtroom was full 
with people from all walks of life, even newspapers sellers and those of dishonorable pursuits came to watch. The scene in the courtroom was chaotic. Onlookers were standing on the cupboards, chairs, and exits of the court." ${ }^{, 15}$

This time, Safia sent someone to represent her at court. At the beginning, Youssef's representative urged the qadi to consider reconciliation. Sadat's representative dismissed the request saying that the Khedive himself intervened and requested reconciliation. Sadat, however, declined the request. Therefore, reconciliation was impossible. Sadat's representative accused Youssef of plotting to conclude the marriage contract without Sadat's permission and approval, which rendered his marriage invalid. He reiterated that Youssef was not equal in status to Safia. In closing, he urged the qadi to divorce the couple as requested in the written pleading submitted to him.

Safia's representative then took a turn, submitting a letter of pleading written by Safia. In her defense, Safia strongly protested the decision of separation because "I was absent when the hearing was held, while no notifications [of appearance were sent to me as required in the LTMS of 1897], and because [the qadi] ruled that I shall be handed over to my father, my adversary in this dispute, and I am fearful of the consequences of my return to him." For these reasons, Safia decided "not to go back to him at any cost." Safai also clarified that

I did not choose sheikh Ali Youssef as my husband until after I ensured that he was more than equal to me in terms of linage and wealth, and that he was of high social status. As I am of age and responsible for my own decisions, I have the ultimate right to marry any man I consider suitable for me at all levels, a right that sharia granted to every single Muslim woman 
who is of age and mature. God gave me this right, and no one can rave it from me.... I am complacent with my husband, and I desire him. I would not desert him at any cost. I married him by free will and out of desire and according to the shari rules of marriage. He proposed to me and I agreed. I received a [suitable] dowry as specified in the marriage contract. I decided to conclude the marriage on my own at the house of the closest relative to me after my father kept rejecting equal [men] asking the hands of his daughters, without any consideration of the rights God granted to them. ${ }^{16}$ Elaborating on Safia's written pleading, Safia's representative said that Safia's father indicated to her that he received her dowry from Youssef and saved it. Sadat, however, kept delaying conclusion of the marriage, just as he did with her other sisters, causing them to remain spinsters. As she did not want to face the same fate, Safia chose the most honorable way to free herself from this prison, concluding the marriage at the house of the closest relative to her, with the preacher of al-Azhar conducting the ceremony and one of its teachers serving as her appointed guardian. By the end of the hearing, the qadi set July 27 as the date for the next hearing. ${ }^{17}$

The hearing of July 27 was devoted completely to addressing the Egyptian government's delay to carrying out the qadi's decision of separation and the hand-over of Safia to her father. As the adversaries were called upon, the qadi declared that he received a note from the qadi of miser protesting the government's postponed implementation the decision in question, requesting that trail of the case of sahib alMoayyed be suspended until the decision was carried out.

The qadi then announced that

Since I am acting on his behalf [the qadi of miser] in adjudicating this case, and since he wanted me to suspend hearing of this case until the decision[of separation] is carried out, and since it is impossible to proceed with the trail 
[while the government kept ignoring the court's order], for these reasons, I decided to defer hearing of the case indefinitely, until he [the qadi of miser] reaches an agreeable solution with the administration regarding this matter and gives me permission [to proceed with the trail.] I'm informing the adversaries about this development. ${ }^{18}$

Certainly, the qadi's decision to indefinitely suspend the trail signaled an uncompromising position, creating an impasse that was apt to escalate. The Egyptian government, however, compromised and agreed to a mediated solution: Safia was to stay at the house of sheikh Abd al Kader al Rafiee, one of the senior ulama of al Azher and a friend of Sadat, until a decision regarding her marriage status was made. ${ }^{19}$ Undoubtedly, separating Safia from Youssef was a victory for the ulama and a show of their ability to challenge political power. The ulama were prepared to and confident about imposing hardship on Youssef and Safia for their perceived violation of the established social norms and rules.

The Decision

On August $11^{20}$, the qadi stated his ruling regarding the case of sahib al-Moayyed. The qadi's judgment included a detailed summary of the arguments made, and the evidence presented by the disputed parties, as well as his response to them. The position of each side were reiterated and clarified.

The qadi pointed out that the court had established, based on the acknowledgment of both parties and other evidence, that the marriage contract of sheikh Ali Youssef, the 
owner of al-Moayyed, and Safia, the daughter of Ahmed al Sadat, was concluded without the father's knowledge and approval. As a result, a dispute erupted between the father and the couple over the validity of the marriage contract. Sadat's representative claimed that the marriage contract was invalid because Youssef and Safia concluded it without the permission and approval of Sadat, while Youssef was not equal to Sadat, and by implication, to Safia. According to Sadat's representative, Sadat was sharif(noble) and husseini (descendant of the Prophet) while Youssef was not sharif, not even of Arab origin, and only his name, Youssef, was of Islamic origin. Other than his name, Youssef was unknown. In addition, Youssef's occupation rendered him unequal to Sadat who was sheikh sajada [head of a Sufi order], and a supervisor of his ancestors' awqaf, a job by which he made a living. Furthermore, Sadat's household enjoyed high social status and a long-standing glory, whereas Youssef belonged to a degraded, poor family the members of which were servants until circumstances changed in Youssef's favor and he became wealthy and famous.

Representatives of the defendants, on the other hand, maintained that the marriage contract was valid. Explaining why the marriage was concluded without Sadat's knowledge and permission, representatives of the defendants claimed that Sadat thwarted not only the marriage of Safia, but also that of his aunt, two sisters, and other daughters. Representatives of the defendants maintained that Sadat agreed to the marriage arrangement and accepted Youssef as Safia's future husband and informed many people about this agreement. Furthermore, Sadat accepted accustomed gifts from Youssef as a 
fiancé and future husband of safia, and above all, Sadat received Safia's dowry. Representatives of the defendants stressed that Youssef was equal to Sadat in terms of wealth, lineage, religion, occupation, social status and influence, and all matters of equality. The representative even claimed that Youssef had greater status than Sadat.

Youssef's representative denied that Sadat was sharif at all, while claiming that Youssef was. According to the representative, Youssef was wealthier and more pious than Sadat. While Youssef had an honorable occupation, Sadat had no job. Youssef was an alim and enjoyed more influence than Sadat, since hassab (influence) was measured in terms of fame, and Sadat had often benefited from this fame.

Addressing the claims of the parties, the qadis stated that as for Islam and freedom, neither the defendants nor the plaintiff questioned them. With respect to the claim that Sadat was an obstacle, preventing his daughters from getting married, this claim was dismissed because Youssef and Safia failed to provide enough evidence demonstrating it. The qadi stated that conclusion of the marriage contract without Sadat's knowledge and approval, was a violation of the shari familial morals.

The qadi then pointed out that the defendants were unable to present proof showing that Sadat received the dowry and gifts from Youssef, and that Sadat, after having received them, kept postponing conclusion of the marriage. Even had they been able to demonstrate this claim, reception of the dowry and acceptance of gifts did not in themselves mean that Sadat agreed to the marriage. According to sharia, if the guardian 
initially accepted the dowry but discovered later that the potential husband was not equal to him, acceptance of the dowry would not amount to proof of agreement to the marriage. The marriage contract in this situation was concluded without the approval and permission of the guardian. According to the prevailing hanifi opinion, the mature woman of age could conclude marriage on her own without the agreement and permission of her guardian. Her marriage would be regarded valid provided that the husband was equal to her and the dowry was suitable to her status. However, the marriage would not be considered valid if the husband was not equal, or the dowry did not match her status.

Youssef claimed that he received higher education, citing a number of books (classes) he took at al-Azhar and other institutions as evidence of this higher education. Youssef, however, did not complete his study at al-Azhar, hence, did not obtain al almyeea, which al fuqaha considered as enough evidence of equality and suitability in marriage. Since possession of al-almyeea was not proven, it was impossible to demonstrate equality based on education.

To demonstrate his lineage, Youssef depended on the testimony of eyewitnesses and the records of al sharif association and that of al waqfs of al Ashraf. The testimony of these eyewitnesses had been dismissed because the eyewitnesses were unable to accurately trace Youssef's lineage, and because there were discrepancies in their accounts. As for the claim that the lineage of Youssef and his household was specified in details in the record of al Ashraf association, the record of this association was based on 
reports that did not, from the shari perspective, serve as proof of the lineage. Youssef also failed to present documents from the record of al-Azhar testifying to his lineage.

On the other hand, to prove his own lineage, Sadat had many sources. He relied on Youssef's explicit recognition, the testimony of eyewitnesses, faramanat, official reports, books, and public reputation in order to prove the nobility of his lineage. Sadat cited Youssef's statements in various articles published in al-Moayyed, both before and after the dispute took place, in which Youssef referred to Sadat as hosani and sharif, and acknowledged the fame, influence and the esteemed status of Sadat and his family dating back 700 years. In addition, faramanat, history books, and official letters, all showed clearly that the jah (status and weight) of Sadat's household was a longstanding one. The fame of Sadat's family, the qadi affirmed, was therefore beyond doubt and could not be questioned.

Youssef did not claim that his descendants were of fame, wealth, or influence. He only attributed these merits to himself. The reason behind requiring equality in marriage was to prevent aar (disgrace) as understood in araf(custom), which defined hassab and jah as the ancestors' merits and attributes of which the descendants would be proud. Therefore, Youssef was not equal to Sadat in terms of hassab.

Sadat, conversely, claimed he was of hassab just the same as his descendants, growing up with this hassab, while Youssef grew up as a servant, just like his descendants. Therefore, Youssef did not grow up with hassab, a fact, the qadi concluded, 
that Youssef did not deny, as he did not claim to have grown up with hassab. Youssef only acknowledged to have become of hassab lately, hence, admitting he did not have jah initially. This was very well known in Egypt, the qadi affirmed. "That Youssef lacked jah previously is an established fact, the denial of which cannot be accepted," the qadi added.

With regard to Youssef's occupation, the qadi said the sharia identified three objectives for the pursuit of journalism: to educate the people, to advise polity and society, and to advance one's own interests at any cost. While the first and second objectives were honorable ones, the third category, to which the qadi is associated Youssef, was shamefaced.

In closing the qadi declared that "Since the marriage contract of sheikh Ali Youssef Sahib al Moayyed and Safia Ahmed Abdul Khaliq al Sadat was concluded while sheikh Ali Youssef was not equal to Ahmad Abdul Khaliq al Sadat, for these reasons, the marriage contract is not valid. Therefore, the couple shall not stay together any longer."

The qadi's decision was received with jubilance and satisfaction from the crowd, as well as those who conceived the case of sahib al-Moayyed as essentially representing a battle between the defenders of the sharia and those who sought to undermine it. Once the qadi announced the verdict in favor of Sadat, the audience, which was great in number, uttered loudly "Long live sharia, long live justice." One of the Egyptian notables attending the hearing shouted: "Kiss his [the qadi] hand, Muslims." The crowd rushed to the qadi and "started kissing his hands and clothing, and were falling one on the other."21 
As far as al Lowa newspaper was concerned, the case of sahib al-Moayyed was important on social, as well as religious levels. Al Lowa expressed the concern that if this case ended in favor of Youssef and the political authorities backing him,

It would have been a big blow to the authority of the fathers over their daughters in Egypt, completely destroying this authority. Fortunately, Muslim morals and familial customs in Egypt found protectors who are zealous to protect Muslim virtues, raising their voices against this terrible matter [allowing Muslim women to conclude marriage on their own], refusing to yield to the political authority, finding support from the public as well as the distinguished men [the ulama]. Men of the shari courts, the distinguished ulama, defended the sharia, and succeeded in undermining those who sought to permit what God prohibited, and forced them to abide by the shari rules. ${ }^{22}$

Even though Youssef dismissed the ruling as unjust and promised to contest it, which he did, his case was a losing one, significantly weakened by the reputation his marriage acquired. It should not come as a surprise, therefore, that the shari Court of Appeal confirmed the judgment against him. ${ }^{23}$

As it seems, the ulama appear to have been rigid with regard to their stance to the case of sahib al-Moayyed. This inflexibility, however, should be seen and understood as the outcome of the pressures placed by the modernization program and Western domination. Defending Muslim cultural norms and values was their approach and conscious coping strategy to protect and sustain the long-standing social order in the face of the massive invasion of the modern ones. It also ought to be as an affirmation of the ulama of their position as the only experts in God's law. 
Notes to Chapter Four

1. Hallaq. "Juristic Authority."

2. Majlis shora al-quaneen: majmuat mahadir jalasat sanat 1896-1897-1898-1899, jalaset 10 mayo (Cairo: Matbaat fathallah al-yaas wa awadeh, 1900), 30-38.

3. Al-Mahakim, May 21, 1899.

4. Al-Hokook, May 31, 1899.

5. Al-Raaed al-Masri, June 06 and 09, 1899.

6. Al-Moayyed, May 30, 1899.

7. Al-Raaed al-Masri, June 06 and 02, 1899.

8. Al-Moayyed, June 01, 1899.

9. Al-Hokook, June 03, 1899, al-Raed al-Masri, June 06 and 09, 1899.

10. Hilmi, Namnam, Ali Yusuf wa Safiyah al-Sadat: rasail al-hubb wa-marakat alzawaj (Cairo: Mirit lil Nashr wa al-malumat, 2001).

11. Al-Liwaa and al-Mokattam, July 15, 16, 17, 18, 19,20, 1904.

12. Majid, Khadduri and Herbert J Liebesny, Law in the Middle East (Washington: Middle East Institute), 138-40, and Ali Kecia, Marriage and Slavery in Early Islam (Cambridge: Harvard University Press, 2010), 42.

13. Al-Liwaa, al-Mokattam, and al-Moayyed, July 26, 1904. 
14. Al-Moayyed, July 27, 1904.

15. Ibid, Al-Liwaa, and al-Mokattam July 27, 1904,

16. Al-Liwaa, al-Mokattam, and al-Moayyed, July 27, 1904.

17. Ibid, July 28, 1904.

18. Ibid, August 05, 1904.

19. Ibid, August 12, 1904

20. Ibid.

21. Ibid.

22. Ibid. October 24, 1904. 


\section{Conclusion}

In recent decades, modernization theory has largely been discredited. Many accounts and assumptions that were based on this theory have been challenged or revised. Like other topics, earlier studies investigating the outcome of the encounter between the Egyptian ulama and the modern world have oriented their research around hypotheses of the modernization theory. Conclusions of these studies - which continue to be unverified and to infuse scholarly literature-have proven to be more generalized assumptions than nuanced descriptions of what really happened.

According to the established academic account, the modernization program in Egypt, initiated by the powerful Muhammad Ali and pursued by his successors throughout the nineteenth century and beyond, had devastating and lasting consequences on the status of the Egyptian ulama and their influence in general. Chiefly, modernization resulted in the loss by the Egyptian ulama of both their economic resources and power to the state and the deterioration of their political and social influences in society and polity alike. In the aftermath of modernization, the ulama became effectively weak, disabled, and completely submissive to the political establishment. According to established scholarly opinion, the ulama were mere reactionaries. While opposing reform programs and disqualifying innovations of any type, the Egyptian ulama did not actually put forth any initiatives. In essence, the old-fashioned ulama failed to deal with, let alone to grasp, overwhelming changes brought about by modernity. 
The evidence revealed throughout this study offers invaluable insights that has helped construct a clearer picture of precisely how the Egyptian ulama conceived modernity, how actively they approached it, and how they participated in the making of modern Egypt.

During a period that witnessed vigorous attempts to transform Egypt into a modernized country and a part of the modern world, the Egyptian ulama stood out and served as custodians of change. As elsewhere in the Muslim world, modernity posed to the Egyptian ulama a serious question the right answer to witch was never easy: how to adapt to massive and unrelenting patterns of change introduced by modernity and to be integrated into the modern world while preserving one's distinctive identity and essence at the same time?

The Egyptian ulama had served as custodians of change for centuries. They had long and rich tradition. They had much history to draw from. Based on their collective, profound experience with change, the Egyptian ulama appear to have generated the following response to modernity. To adjust to change, the Egyptian ulama accepted the adoption of certain elements of modernity, while dismissing other components as unnecessary or harmful. Observing the nature of the transformation of the shari court system, the Egyptian ulama permitted modern techniques to be introduced to operations of this system, buy they resisted alternations to the law itself.

The Egyptian ulama comprehended and admitted modernity as useful 
technological advances and techniques, but rejected too swiftly embracing the entire cultural and social aspects of it. Thus, while accepting particular changes made at state level, the Egyptian ulama resisted attempts to bring about rapid and deep alterations to the social structure, stressing that Islamic cultural norms and values constituted the core and they ought to be preserved.

In doing so, the ulama may have been motivated by a concern that society might fall apart and Egypt might develop into a chaotic country, one that could stray from its ideals if social change was abruptly imposed and the longstanding social order was suddenly destroyed. For the Egyptian ulama, change would happen, but it had to be gradual and carefully calculated to maintain order, stability, and progression. The foundation could be maintained and revived by allowing gradual evolution rather than risking the instability of giving it up altogether and at once and replacing it with a completely new one.

The role of the Egyptian ulama in modern Egypt remained both critical and relevant. By making a successful defense of their longstanding position as the ultimate authority over family law as they did in May of 1899 , hence, maintaining a close relationship with the basic unit of society, the family, while preserving their role as guardians of Muslim culture as they did in 1904(the case of sahib al-Moayyed), the Egyptian ulama were able to prevent profound and quick social transformation to be carried out from the top and imposed on the people. Therefore, the scope and outreach of modernization was effectively limited. Secularization failed to attract enough followers 
among the Egyptians to induce the real and deep social change envisioned by proponents of modernity. Islamic cultural values and norms continued to be embraced and highly esteemed among the vast majority of the Egyptian people.

Historically, the Egyptian ulama served as a legal, political, moral, and social force at the same time. As this study stresses, the main source of their significance in society and polity alike was largely their social influence. Their reliance on their strong connection and close association with the masses as a means to maintain importance and generate authority helped the Egyptians ulama sustain their political impact and other influences.

In the face of powerful political elites aggressively seeking to shape and reshape Egypt in accordance with modern parameters, the Egyptian ulama used their social influence as a tool to impact or confront political power and to set limits to change. The social influence of the Egyptian ulama took the form of the exercise of moral reward and sanction over the political power, public opposition to it, or the threat of a revolt. The Egyptian ulama were also empowered by the heavy dependence of the Egyptian regimes on the ulama for legitimacy.

As a result of the Egyptian ulama's influence, modern legal reform in Egypt, as well as the emergence of the modern state in this country as a bearer of legal authority, both were explained and justified in Islamic terms, hence, recognizing and emphasizing Islam as a powerful and indispensable source of political legitimacy. Rather than 
weakening the influence and significance of Islam, therefore, modernization had indeed reinforced the role of Islam as the principle source of legitimacy.

The emergence of radical Islam and the Islamists in the public sphere in the course of the second half of the twentieth century as a notable social and political force claiming to truly represent Islam and posing a serious challenge to the legitimacy of the political establishment, speaks volumes about how the Egyptian ulama were successful in preserving the role of Islam as a major force in society and as the main source of legitimacy. The Islamists, who resorted to violence to bring about political change, charged the ulama with being submissive to the political power, and accused the latter of departing from Islamic ideals. The emergence of the Islamists led to the restoration of the Egyptian ulama's role as peace brokers, experts in the sharia, and legitimizers of political power. Once again, the political powers in Egypt found themselves in dire need of the support of the ulama who were the only authority capable of confronting the Islamists in the public sphere where state influence and presence remained absent.

If the far-reaching objective of the Egyptian ulama was to sustain Islam as the major force in society and polity alike during a period that witnessed the making and remaking of modern Egypt, then the Egyptian ulama were successful with history on their side. In the end, Islam remained in independent Egypt a social and political force, a powerful one that was capable of shaping and reshaping the very fabric of society. 


\section{Bibliography}

Abduh, Muhammad. Taqrir fi iṣlaḥ al-mahakim al-shar 'iyah. Cairo: Maṭbaah al-manar, 1900.

Akhavi, Shahrough. Religion and Politics in Contemporary Iran: Clergy-State Relations in the Pahlavī Period. Albany: State University of New York Press, 1980.

Al-Ahram. January 18, 1884.

----- March 14, 1888.

Alami, Dawoud el and Doreen Hinchcliffe. Islamic Marriage and Divorce Laws of the Arab World. Cambridge: Kluwer Law International, 1996.

Al-Hokook. May 31, 1899.

----- June 03, 1899.

Al-Liwaa. July 15, 16, 17, 18, 19,20, 26, 27 31, 1904.

Al-Raaed al-Masri. June 02, 06,09, 1899.

----- June 06, 1899.

----- June 09, 1899.

----- February, 121901.

Al-Mahakim. August 8 and 15, 1897

----- September 26, 1898. 
----- May 21, 1899.

----- June 21, 1907.

----- July 09, 1908.

Al-Moayyed. September 13, 1893.

----- May 30, 1899.

----- June 01, 1899.

----- November 28, 1899.

----. May 16, 1900.

----- July 26, 27, 281904.

----- August 05, 121904.

----- October 24, 1904.

----- June 01, 1907.

Al-Moqatam. October10, 1894.

----- July 15, 16, 17, 18, 19,20, 26, 271904.

Amir ali bi-insha madrasat al-qada al-shari fi February, 25 1907. Dar al wathaak al qomia, mahafez abdeen, mahfaza 1.

Amin, Ahmad. Hayati. Cairo: Maktabat al-ahḍah al-mișriyah, 1961.

Amin, Sami. Taqwim al-Nil. Vol 1,2,3. Cairo, al-Matbaah al-Amiriyah, 1915. 
Anderson, Benedict R O'G. Imagined Communities: Reflections on the Origin and Spread of Nationalism. London: New York: Verso, 1991.

Aroian, Lois A. The Nationalization of the Arabic and Islamic Education in Egypt: Daral-Alum and al-Azhar. V. 6, Monograph 4. New York: American University in Cairo, 1983.

Gabriel, Baer. "Tanzimat in Egypt--The Penal Code." Bulletin of the School of Oriental and African Studies, University of London. Vol. 26, No. 1, 1963: 29-49.

Gelvin James L. and Nile Green. Global Muslims in the Age of Steam and Print. Berkeley: University of California Press, 2013.

Barraclough, Steven. "al-Azhar: Between the Government and the Islamists.” Middle East Journal 52 (1998), 236-249.

Berkey, Jonathan Porter. The Formation of Islam: Religion and Society in the Near East, 600-1800. New York: Cambridge University Press, 2003.

Brown, Nathan J. The Rule of Law in the Arab World: Courts in Egypt and the Gulf. New York: Cambridge University Press, 1997.

Brinton, Jasper. The Mixed Courts of Egypt. New Haven, 1930.

Campo, Juan E. Encyclopedia of Islam. Facts On File. New York, 2009.

Cannon, Byron. Politics of Law and the Courts in Nineteenth-Century Egypt. Salt Lake City: University of Utah Press, 1988. 
Chamberlain, Michael. Knowledge and social practice in Medieval Damascus. New York: Cambridge University Press 1994.

Chamders, Richard L. Beginnings of Modernization in the Middle East: The Nineteenth Century. Edited by Richard L Chamders. Chicago: University of Chicago Press, 1968.

Cooper, John, Ronald L. Nettler, and Mohamed Mahmoud. Islam and Modernity: Muslim Intellectuals Respond. London: Tauris, 2000.

Crecelius, Daniel. "Non-Ideological Responses of the Egyptian Ulama to Modernization." In Sufis, Saints and Scholars. Edited by Nikki Heddie, Berkeley: University of California Press, 1972.

Danasuri, Fahim Hafiz. Ahmad Amin wa al-tharuhu fi al-Lughah wa-al-Naqd al-Adabi. Cairo: Maktabat al-malik fayṣal al-islamiyah, 1986.

Donohue John J. and John L. Esposito. Islam in Transition: Muslim Perspectives. New York: Oxford University Press, 2007.

Eickelman, Dale F., and James Piscatori. Muslim Politics. Princeton: Princeton University Press, 1996.

Esposito, John L. The Oxford of Islam. New York: Oxford University Press, 1999. Islam and Development: Religion and Sociopolitical Change. Edited by John Esposito. New York: Syracuse University Press, 1980. 
Esposito, John L. and John Obert Voll. Makers of Contemporary Islam. New York: Oxford University Press, 2001.

Gailey, Christine Ward. Dialectical Anthropology: Essays in Honor of Stanley Diamond. Edited by Christine Ward Gailey. University Press of Florida, 1992.

Gasper, Michael Ezekiel. The Power of Representation: Publics, Peasants, and Islam in Egypt. California: Stanford University Press, 2009.

GershonI, Israel, and James P Jankowski. Redefining the Egyptian Nation 1930-1945. Cambridge and New York: Cambridge University Press, 1995.

Fahmy, Khaled. "The Anatomy of Justice: Forensic Medicine and Criminal Law in Nineteenth-Century Egypt." Islamic Law and Society, Vol. 6, No. 2, The Legal History of Ottoman Egypt, 1999: 224-271.

Farahat, Muhammad Nur. Al-tarikh al-ijtimai lil-qanun fi miser al-hadithah. Cairo: markaz ibn khaldun lil-dirasat al-inmaiyah, 1986.

Hallaq, Wael B. "Juristic Authority vs. State Power: The Legal Crises of Modern Islam." Journal of Law and Religion, Vol. 19, No. 2, 2004: 243-258.

Hanki, Aziz. “Al-tashri wa al-qada qabla insha al-mahakim al-ahliya.” In al-kitab aldhahabi lil-mahakim al-ahliyah 1883-1933. Cairo: Al-matbaah al-amiriyah bibulaq, 1937.

Hatina, Meir. Ulama, Politics, and the Public Sphere: An Egyptian Perspective. Salt Lake 
City: University of Utah Press, 2010.

Heyd, Uriel, and V.L. Menage. Studies in Old Ottoman Criminal Law. Oxford: Clarendon Press, 1973.

Holt, P.M. Political and Social Change in Modern Egypt: Historical Studies from the Ottoman Conquest to the United Arab Republic. Edited by P.M Holt. London: Oxford University Press, 1968.

Hourani, Albert. Arabic Thought in the Liberal Age, 1798-1939, (Cambridge and New York: Cambridge University Press, 1983)

------ A History of the Arab Peoples (Cambridge, Mass: Belknap Press of Harvard University Press, 1991)

Jumayi, Abd al-Munim Ibrahim al-Dusuqi. Madrasat al-qada al-shari: Dirasah tarikhiyah li-muassasah talimiyah 1907-1930. Cairo: Maktabat al-Khanji bi-Mișr, 1986.

Kandiyoti, Deniz. Women, Islam, and the State. Philadelphia: Temple University Press 1991.

Kecia, Ali. Marriage and Slavery in Early Islam. Cambridge: Harvard University Press, 2010.

Kepel, Gilles. Muslim Extremism in Egypt: The Prophet and Pharaoh. Berkeley: University of California Press, 2003. 
Kramer, Martin. Political Islam. Beverly Hills: Sage Publications, 1980.

Kramer, Gudrun, and Sabine Schmidtke. "Introduction: Religious Authority and Authorities in Muslim Societies: A Critical Overview.” In Speaking for Islam: Religious Authority and Authorities in Muslim Societies. Edited by Gudrun Kramer and Sabine Schmidtke, 1-14. Leiden, Brill 2006.

Lapidus, Ira M. A History of Islamic Societies. New York: Cambridge University Press, 2014.

Layihat tartib al-mahakim al-shariyah wa-al-ijraat al-mutaalliqah biha fi mayo 281897. Cairo: Al-mațbaah al-hindiyah, 1897.

Layihat tartib al-mahakim al-shariyah wa-al-ijraat al-mutaalliqah biha fi May, 17, 1880. Cairo: al-mațbaah al-amria, 1880.

Layihat tartib al-mahakim al-shariyah wa-al-ijraat al-mutaalliqah biha fi 1910. Cairo: Maṭbaah al-ummah, 1910.

Lippman, Matthew Ross, Seán McConville, and Mordechai Yerushalmi. Islamic Criminal Law and Procedure: An Introduction. New York: Praeger, 1988.

Majlis shora al-quaneen: Majmuat mahaḍir jalasat sanat 1896-1897-1898-1899. Cairo: Matbaat fathallah al-yaas wa awadeh, 1900.

Mitchell, Timothy. Colonizing Egypt. Cambridge and New York: Cambridge University Press, 1988. 
Mitchell, Timothy. Rule of Experts: Egypt, Techno-Politics, Modernity. Berkeley: University of California Press, 2002.

Moustafa,Tami. "Conflict and Cooperation between the State and Religious Institutions in Contemporary Egypt.” International Journal of Middle East Studies, Vol. 32, No. 1 (Feb., 2000) 3-22.

Mudhakkirat Saad Zaghlul 1857-1927. Tahqiq abd al-azim Muhammad Ibrahim Ramadan. Cairo: Al-hayah al- mișriyah al-ammah lil-kita1987.

Nahal, Galal H El. The Judicial Administration of Ottoman Egypt in the Seventeenth Century. Minneapolis: Bibliotheca Islamica, 1979.

Namnam, Hilmi. Ali Yusuf wa Safiyah al-Sadat: rasail al-hubb wa-marakat al-Zawaj. Cairo: Mirit lil Nashr wa al-malumat, 2001.

Najja, Fauzi M. "Egypt's Laws of Personal Status.” Arab Studies Quarterly Vol. 10, No. 3, Summer 1988.

Peters, Rudolph. "The Codification of Criminal Law in Nineteenth-Century Egypt: Tradition or Modernization?' In Law, Society and National Identity. Edited by J.M. Abun-Nasr, U. Spellenberg, and U Wanitzek. Hamburg, 1990,

----- "For His Correction and as a Deterrent Example for Others: Meḥmed 'Alī's First Criminal Legislation (1829-1830)." Islamic Law and Society, Vol. 6, No. 2:64192. 
-----“Islamic and Secular Criminal Law in Nineteenth-Century Egypt: The Role and Function of the Qadi." Islamic Law and Society, Vol. 4, No. 11997.

----- “The Origins of Pre-1883 Egyptian Penal Legislation,” Paper presented to the 1996 Annual MESA Meeting.

Petry, Carl F. The Civilian Elite of Cairo in the Later Middle Ages. Princeton, N.J.: Princeton University Press, 1981.

Pollard, Lisa. Nurturing the Nation: The Family Politics of Modernizing, Colonizing and Liberating Egypt (1805/1923). Berkeley: University of California Press, 2005.

Rashotte, Lisa Slattery. "Social Influence." In The Concise Blackwell Encyclopedia of Sociology. Edited by George Ritzer and J. Michael Ryan. Oxford Blackwell Publishing: 2011.

Reid, Donald Malcolm. "Al.Azhar." The Oxford Encyclopedia of the Islamic World. Oxford Islamic Studies Online, http://www.oxfordislamicstudies.com/article/opr/t236/e0091.

Salim, Latifa. Al-nizdm al-qadd'l al-misri al-hadith, 1875-1914. Cairo: Al-Ahram Center for Political and Strategic Studies, 1984.

Sharabi, Hisham. Arab Intellectuals and the West: The Formative Years, 1875-1914. Baltimore: Johns Hopkins Press, 1970.

Sivan, Emmanuel. Radical Islam: Medieval Theology and Modern Politics. New Haven: 
Yale University Press 1990.

Zubaida, Sami. Law and Power in the Islamic World. New York: I.B. Tauris, 2003.

Shihatah, Shafiq. Tarikh ḥarakat al-tajdid fi al-nuẓum al-qanuniyah fi miṣr mundhu ahd Muhammad Ali. Cairo: jamiyah al-malakiyah lil diradat al tarikhiyah, isa al-babi al-halabi, 1961.

Smith, Donald Eugene. Religion and Political Modernization. New Haven: Yale University Press 1974.

Toledano, Ehud. State and Society in Mid-Nineteenth-Century Egypt. Cambridge: Cambridge University Press, 1990.

Tucker, Judith. Women in Nineteenth-Century Egypt. Cambridge: Cambridge University Press, 1985.

Voll, John Obert. Islam, Continuity, and Change in the Modern World. Syracuse: Syracuse University Press: 1994.

Yafeh, Hava Lazarus. “Continuity and Innovation in Islam: The Ulama vis-à-vis.” In Egypt from Monarchy to Republic: A Reassessment of Revolution and Change, edited by Shimon Shamir. Boulder: Westview Press 1995.

Zayd, Nasr Hamid Abu. Reformation of Islamic Thought: A Critical Historical Analysis. Amsterdam: Amsterdam University, 2006.

Zaman, Muhammad Qasim. The Ulama in Contemporary Islam: Custodian of Change. 
Princeton: Princeton University Press, 2002.

Zegha, Malika. "Religion, and Politics in Egypt: the Ulema of al-Azhar, Radical Islam, and the State(1952-94).” International Journal of Middle East Studies 31 (1999) 371-399.

Ziadeh, Farhat. Lawyers, the Rule of Law and Liberalism in Modern Egypt. Stanford: Hoover Institution, 1968. In Honor of Stanley Diamond. Edited by Christine W. Gailey. Gainesville: University of Florida Press, 1992. 